\title{
Irresponsible Lending in the Post-Crisis Era: Is the EU Consumer Credit Directive Fit for Its Purpose?
}

\author{
Olha O. Cherednychenko ${ }^{1}$ (D) - Jesse M. Meindertsma ${ }^{1}$
}

Received: 29 July 2018 / Accepted: 21 June 2019 / Published online: 24 August 2019

(C) The Author(s) 2019

\begin{abstract}
More than a decade after the outbreak of the global financial crisis, consumers across the EU have been increasing their level of debt in terms of both volume and value of consumer credit products. Among the reasons for this trend are the low interest rate environment, the novel business practices of lenders aimed at finding new revenue sources, such as fees and charges on loans, and the innovative business models emerging in an increasingly digital marketplace, such as peer-to-peer lending. These developments present new risks to consumers and pose new challenges for regulators in terms of how to address them. This article aims to uncover the problematic aspects of consumer credit provision in the post-crisis lending environment across the EU and to assess to what extent the 2008 Consumer Credit Directive currently in force, which aims to ensure adequate consumer protection against irresponsible lending, is fit for its purpose today. In this context, the article explores the general meaning of "responsible lending" with emphasis on consumer credit, identifies the most imminent irresponsible lending practices in the consumer credit markets, and tentatively analyses their key drivers. It also reveals some important limitations of the Consumer Credit Directive in providing adequate consumer protection against irresponsible lending and offers tentative recommendations for
\end{abstract}

\footnotetext{
${ }^{1}$ Olha O. Cherednychenko is Professor of European Private Law and Comparative Law and Director of the Groningen Centre for European Financial Services Law (GCEFSL) at the University of Groningen (the Netherlands). ${ }^{2}$ Jesse M. Meindertsma is a Ph D Researcher at the Groningen Centre for European Financial Services Law (GCEFSL), University of Groningen (the Netherlands).
}

This article builds on the studies prepared by the authors for the European Parliament's Committee on Economic and Monetary Affairs (ECON) and the European Commission Directorate-General for Financial Stability, Financial Services and Capital Markets Union (FISMA). See O.O. Cherednychenko \& J.M. Meindertsma, Misselling of financial products in the European Union: Consumer credit, Study for the European Parliament's ECON Committee, June 2018 and O.O. Cherednychenko, Irresponsible consumer credit lending across the EU in the post-crisis era, Study for the European Commission DG FISMA, June 2018, respectively.

\section{Olha O. Cherednychenko}

o.o.cherednychenko@rug.nl

Jesse M. Meindertsma

j.m.meindertsma@rug.nl

1 Groningen Centre for European Financial Services Law (GCEFSL), University of Groningen, Groningen, Netherlands 
improvement. In the authors' view, the time now seems ripe for striking a different balance between access to credit and consumer protection in European consumer credit law.

Keywords Consumer credit · Responsible lending - Consumer credit directive $\cdot$ High-cost credit . Cross-selling $\cdot$ Peer-to-peer lending

\section{Background}

More than a decade after the outbreak of the global financial crisis, consumers across the European Union (EU) have been increasing their level of debt in terms of both volume and value of consumer credit products (European Banking Authority 2017, pp. 4, 8). Among the reasons for this trend are the low interest rate environment, the novel business practices of lenders aimed at finding new revenue sources, such as fees and charges on loans, and the innovative business models emerging in an increasingly digital marketplace, such as peer-to-peer lending (P2PL) (European Banking Authority, 2017 pp. 4, 8). These developments present new risks to consumers and pose new challenges for regulators in terms of how to address them. The problem of irresponsible consumer credit lending deserves special attention in this context. Such lending may cause unsustainable levels of overindebtedness resulting in major consumer detriment. In addition, it may be disruptive to the functioning of the EU's single market in financial services.

The central piece of EU legislation currently governing the provision of consumer credit the 2008 Consumer Credit Directive ${ }^{1}$-aims at facilitating "the emergence of a well-functioning internal market in consumer credit" 2 and ensuring "that all consumers ( ... ) enjoy a high and equivalent level of protection of their interests," 3 in particular by preventing "irresponsible lending." This directive, which dates back to the pre-crisis period, reflects the information paradigm of consumer protection and the corresponding image of the "average consumer" as a reasonably well-informed, observant and circumspect actor (Cherednychenko 2014, p. 408; Domurath 2013). The idea behind this model is to improve the consumer decision - making process through the rules on information disclosure aimed at redressing information asymmetries between credit institutions and credit intermediaries, on the one hand, and consumers, on the other. Particularly in the aftermath of the financial crises, however, serious concerns have been raised about the effectiveness of the information model in ensuring adequate consumer protection against irresponsible lending practices and the proper functioning of retail financial markets more generally (Atamer 2011; Avgouleas 2009a; Domurath 2013; Garcia Porras and Van Boom 2012; Micklitz 2010; Nield 2012; Ramsay 2012). The review of the Consumer Credit Directive planned for 2019 provides an opportunity to reflect upon this issue.

Against this background, the aim of this article is twofold. First, it seeks to uncover the problematic aspects of consumer credit provision in the post-crisis lending environment across the EU. Secondly, it attempts to assess to what extent the 2008 Consumer Credit Directive is fit for its purpose today as far as the consumer protection against irresponsible lending practices is concerned. The analysis commences with an exploration of the general meaning of "responsible lending" in the context of consumer credit - that is, unsecured credit provided for

\footnotetext{
${ }^{1}$ Directive 2008/48/EC of the European Parliament and of the Council of 23 April 2008 on credit agreements for consumers and repealing Council Directive 87/102/EEC (2008) OJEU L 133/66 (Consumer Credit Directive).

${ }^{2}$ Consumer Credit Directive, recital 7. See also Consumer Credit Directive, recital 9.

${ }^{3}$ Consumer Credit Directive, recital 9.

${ }^{4}$ Consumer Credit Directive, recital 26.
} 
personal, household, or domestic purposes. Building upon the contours of the concept of responsible lending that has emerged from this quest, as well as the results of the empirical study conducted by the authors, the article subsequently identifies the most imminent irresponsible lending practices in the consumer credit markets across the EU and tentatively analyses their key drivers. In addition to the desk research, the empirical study involved several semi-structured interviews with the representatives of the consumer organizations and national competent authorities aimed at verifying the preliminary findings and obtaining further information on the problematic aspects of consumer credit, both in old and new Member States. ${ }^{5}$ The article then proceeds to examine to what extent the Consumer Credit Directive adequately addresses the problem of irresponsible lending and analyses consumer protection standards and their enforcement within the broader EU regulatory framework for consumer credit. The latter also includes a number of horizontal EU measures, in particular the Unfair Contract Terms Directive ${ }^{6}$ and the Unfair Commercial Practices Directive. ${ }^{7}$ This analysis reveals some important limitations of the current EU regulatory framework for consumer credit, in particular that of the Consumer Credit Directive, in providing adequate consumer protection against the irresponsible lending practices previously identified. The authors conclude by offering tentative recommendations for improvement and identifying areas for further research.

\section{Conceptualizing Responsible Lending}

\section{General}

In an ideal world, lenders would only grant credit to consumers when the latter can repay it without undue difficulties and when consumer credit or related products suit the consumers' needs. At first sight, acting in the interests of consumers may appear to be in the interests of the creditors themselves given that the latter generally seek to reduce their credit risk - that is, the risk to the lender that the consumer will not repay the credit. In practice, however, the interests of creditors and consumer borrowers do not always coincide. Financial incentives may motivate creditors to lend to consumers who they expect to be profitable even if these consumers are at high risk of suffering substantial detriment. The creditors' interest in minimizing their credit risk thus does not provide a sufficient safeguard against irresponsible lending and resulting consumer detriment.

At present, there is no universally accepted definition of the term "consumer detriment." Given that this article primarily analyses responsible lending from a legal perspective, consumer detriment is understood here in a broad sense and refers to a state of personal

\footnotetext{
${ }^{5}$ The authorities consulted include the European Consumer Organization (BEUC), the Dutch Authority for the Financial Markets (Autoriteit Financielle Markten $(A F M)$ ), the German Federal Supervisory Authority (Bundesanstalt für Finanzdienstleistungsaufsicht (BaFin)), the UK's Financial Conduct Authority (FCA), the French Ministry of Economy and Finance (Ministère de l'économie et des finances), the Bulgarian Ministry of Economy (Ministerstvo na ikonomikata), and the Polish Office of Competition and Consumer Protection (Urzad Ochrony Konkurencji i Konsumentów).

${ }^{6}$ Council Directive 93/13/EEC of 5 April 1993 on unfair terms in consumer contracts (1993) OJ L 95/29 (Unfair Contract Terms Directive).

${ }^{7}$ Directive 2005/29/EC of the European Parliament and of the Council of 11 May 2005 concerning unfair business-to-consumer commercial practices in the internal market and amending Council Directive 84/450/EEC, Directives 97/7/EC, 98/27/EC and 2002/65/EC of the European Parliament and of the Council and Regulation (EC) No 2006/2004 of the European Parliament and of the Council (2005) OJEU L 149/22 (Unfair Commercial Practices Directive).
} 
disadvantage caused by purchasing a credit or related product that does not meet the consumer's reasonable expectations. ${ }^{8}$ In particular, such detriment may be represented by the financial loss resulting from the purchase of a credit or related product that does not yield any substantial benefit to the consumer and/or seriously impairs the consumer's financial situation. This is often the case when a consumer credit product is not designed to satisfy consumer needs, but to generate profits for their manufacturers. What is more, such products may not only cause financial loss to consumers but also lead to social exclusion and even serious health problems associated with overindebtedness and aggressive debt collection practices.

A consumer credit product is a contract whereby a creditor grants or promises to grant credit to a consumer in the form of a loan or other financial accommodation. Consumer detriment may thus result from a contract design of a particular credit product, and, as such, a product is normally embodied in a standard contract, a large number of consumers may be affected. Consumer credit products can be divided into two broad categories: instalment (closed-end) credit and non-instalment (open-end or revolving) credit. Instalment credit requires consumers to repay the principal amount and interest within an agreed period of time in equal periodic payments, usually monthly. Examples of such credit are a car loan and a payday loan. Noninstalment credit allows the consumer to make irregular payments and to borrow additional funds within the agreed limits and period of time without submitting a new credit application. Examples of this type of credit product are a credit card and an overdraft facility. As will be illustrated below, both instalment and non-instalment credit agreements may give rise to consumer detriment, particularly when they concern high-cost credit products.

The risk that the purchase of a consumer credit product results in consumer detriment can be exacerbated by certain lending practices to which creditors and credit intermediaries resort in the distribution process. For example, prior to the conclusion of a credit agreement, these entities may fail to perform an adequate assessment of the consumer's creditworthiness or offer additional financial products which are not suitable for the consumer. As a result, even those financial products that have been designed with due regard to the consumer interests may end up in the hands of consumers who cannot afford or simply do not need them. Moreover, such practices may not only seriously impair the financial health of individual consumers but also have adverse external (third-party) effects, disrupting the consumer credit markets and the EU's single market in financial services as a whole (Grundmann et al. 2015, p. 12 et al.; Micklitz 2015). In particular, irresponsible lending practices may undermine consumer confidence in financial markets and lead to financial instability. ${ }^{9}$

In response to these problems, the concept of responsible lending has emerged. In the following, the meaning of this general concept will be explored in more detail in the light of the existing literature, legislation, and policy documents. An attempt will be made to further operationalize it in the context of consumer credit transactions.

\section{What Is Responsible Lending?}

While the modalities of responsible lending may differ across different legal systems and segments of the consumer credit markets, the major idea behind this concept is that lenders

\footnotetext{
${ }^{8}$ Cf., e.g., the definitions of 'consumer detriment,' in particular 'personal detriment,' in (Europe Economics 2007, p. 3) and Civic Consulting (2017, p. 26).

${ }^{9}$ See, e.g., European Systemic Risk Board, Recommendation of 21 September 2011 on lending in foreign currencies (ESRB/2011/1).
} 
should not act solely in their own interests, but that they should also take into account the consumer borrowers' interests and needs throughout the relationship in order to prevent consumer detriment (cf. Ramsay 2012). Operationalizing the concept of "responsible lending" in the legal context of consumer credit transactions involves the need to translate it into specific duties of lenders towards consumers. Such duties typically go beyond the creditors' and credit intermediaries' duties to inform the consumers about the characteristics of a credit product and include more intrusive obligations aimed at preventing the conclusion of credit agreements that may result in consumer detriment. In this context, a distinction between the consumer credit product design and lending practices in the distribution process becomes particularly relevant.

In our view, an important prerequisite for responsible lending in the consumer credit markets is that consumer credit products are designed in a responsible way - that is, in the best interests of consumers to whom they are marketed. ${ }^{10}$ The importance of financial product design from a consumer protection perspective has been increasingly recognized in the post-crisis era which has witnessed the introduction of the so-called product governance regimes across different areas of financial services (Cherednychenko 2014). Such regimes generally relate to the organizational conduct of business rules that should be observed by financial institutions when developing financial products. In particular, these rules are designed to prevent financial institutions manufacturing financial products that may harm consumers. To the extent that such rules apply in the field of consumer credit, they may profoundly affect the contractual design of consumer credit products, precluding the development of "toxic" consumer credit products which are highly likely to cause consumer detriment. The product features that may be incompatible with the creditors' responsible lending obligations at the product development stage include, for example, denominating a loan in a currency other than that in which consumers receive income (European Financial Inclusion Network Research Working Group on Over-Indebtedness 2016), charging consumers excessively high interest rates, encouraging consumers to make only minimum repayments on a non-instalment loan for an indefinite period, or allowing consumers to endlessly renew an instalment loan where they cannot afford to repay it on due dates.

When it comes to lending practices in the process of distributing consumer credit products, the thrust of responsible lending is that, prior to the conclusion of a credit agreement, the lender should not only assess whether it will recover its money in the case of the consumer borrower's default on a loan - that is, credit risk. ${ }^{11}$ In addition, the lender should at least determine whether the borrower is likely to be able to repay without incurring undue financial hardship and whether a financial product offered together with a credit product is not clearly unsuitable for the consumer's needs and circumstances (cf. Ramsay 2012; Ramsay 2016). The creditors' and credit intermediaries' responsible lending obligations in the distribution process thus include, as a minimum, two major duties aimed at preventing consumer detriment: the duty to assess the consumer's creditworthiness and the duty to judge the basic suitability of a credit-related product for the consumer before considering whether to proceed with a credit transaction.

\footnotetext{
${ }^{10}$ Cf. European Coalition for Responsible Credit (n.d.), Principles of responsible credit, in particular Principle 1: 'Responsible and affordable credit must be provided for all.'

${ }^{11}$ With respect to the assessment of credit risk, see, e.g., European Central Bank (2017). According to the European Central Bank (ECB), non-performing loans are '[1] oans other than held for trading that satisfy either or both of the following criteria: (a) material loans which are more than 90 days past-due; (b) the debtor is assessed as unlikely to pay its credit obligations in full without realization of collateral, regardless of the existence of any past-due amount or of the number of days past due' (Annex 1).
} 
As far as the consumer's creditworthiness assessment is concerned, the distinction between a "lender-focused" and a "borrower-focused" test made by the United Kingdom's FCA is particularly helpful in determining the scope of such an assessment. While a lender-focused test is limited to the assessment of credit risk, a borrower-focused test involves the assessment of credit affordability, which is about how difficult it may be for the consumer to repay credit (FCA 2017a, p. 4). This dichotomy addresses the above mentioned problem that the lender's interest in minimizing its credit risk may not always provide a sufficient incentive for the lender to provide a loan which is in the best interests of the consumer borrower. In order to ensure responsible lending, therefore, the lender's duty to assess the consumer's creditworthiness, in our view, should by no means be limited to the assessment of credit risk and should also include the borrower-focused creditworthiness check.

At present, there is no general agreement about the optimal design of such a test, in particular when it comes to defining the risk which it is supposed to address. Various concepts, such as "overindebtedness" (European Commission 2008), "unsustainable repayments,"12 and "a problematic debt situation,"13 can be found in the literature as well as legislative and policy instruments in this context. While the severity of the consumer debt repayment problems appears to be their common denominator, the existing concepts diverge with respect to the relevant criteria for assessing it. While some focus on the duration of the period within which such problems manifest themselves, others centre around the borrower's payment capacity that can be used for debt repayment. In order to address both concerns prior to the conclusion of each consumer credit transaction, we suggest that the borrower-focused creditworthiness assessment should primarily be designed to address the risk of a problematic repayment situation in which a consumer borrower may find him- or herself after the conclusion of such a transaction. A problematic repayment situation may thus arise if the consumer is persistently unable to repay the debt (a) within a reasonable time and/or (b) in a sustainable way - that is, without having to default on other financial commitments (e.g., energy bills) or having to reduce his or her regular expenditures to a degree which would be harmful to him or her or his or her household (e.g., falling below the minimum living standard). In such a situation, the consumer may feel the need to take out even more credit in order to meet the existing repayment obligations. In order to minimize the risk of a problematic repayment situation and resulting consumer detriment, the duty of responsible lending should, in our view, imply specific obligations of the lender at each of the three steps of the creditworthiness assessment process: (1) obtaining relevant information about the consumer's financial situation, (2) judging the consumer's creditworthiness, and (3) deciding on the consumer's credit application. At each step, the consumer's interests should be taken into account. This could be done in the following way.

Step 1. Obtaining relevant information about the consumer's financial situation.

In the first place, the lender should collect all the information about the consumer's financial situation which is necessary to make a thorough borrower-focused creditworthiness assessment. Apart from information about the consumer's income, therefore, the creditor should also collect sufficient data concerning his or her non-discretionary expenditures, such as living expenses and

\footnotetext{
${ }^{12}$ FCA Consumer Credit Sourcebook, para. 2.5.8 (17). See also FCA Consumer Credit Sourcebook, Glossary Terms, 'unsustainable.'

${ }^{13}$ Preparatory documents for the Dutch Consumer Credit Act (Wet op het consumentenkrediet (WCK)) 1991 which was revised in 2016. E.g., Tweede Kamer der Staten Generaal, Kamerstuk 19,785, nr. 3 (Regels met betrekking tot consmentenkrediet (Wet op het consumentenkrediet)), p. 23.
} 
preexisting loan repayments, as well as other financial and economic circumstances. Furthermore, it is crucial that this information is obtained from reliable internal and external sources. In particular, the information obtained from the consumer must be subject to appropriate verification.

Step 2. Judging the consumer's creditworthiness.

Once the lender has collected the necessary data, it should make a judgement about the consumer's creditworthiness. In this context, a distinction between a creditor-focused and a borrower-focused assessment is particularly important. The creditor-focused test is based on the premise that there is no problematic repayment situation as long as the consumer is able to repay the credit or otherwise meet his or her obligations under the credit agreement (e.g., making minimum repayments on a credit card). For the purposes of this assessment, it is irrelevant how the consumer is able to do so (e.g., by defaulting on other loans). In contrast, the borrower-focused test assumes that there is no problematic repayment situation only as long as the consumer is able to repay credit and meet other obligations under the credit agreement within a reasonable time and in a sustainable manner. In practice, lenders may combine both aspects into a single assessment, and there may be considerable overlap between the two (cf. FCA 2017a, p. 4). What responsible lending at this step should ensure is that appropriate account is taken of the consumer borrower's interest in repaying the credit where it is not fully aligned with the lender's interest in minimizing the credit risk.

Step 3. Deciding on the consumer's credit application.

Once the lender has determined whether the consumer is creditworthy, it can decide on the consumer's credit application. The key issue to be addressed at this stage is what to do in case of the negative outcome of the creditworthiness test. The idea behind responsible lending suggests that in such a case the lender should take reasonable steps to protect the consumer against the risk of a problematic repayment situation. These steps may include warning the consumer about this risk or even not granting any credit in certain circumstances.

Apart from the duty to assess the consumer's creditworthiness, the concept of responsible lending also implies another major obligation of creditors and credit intermediaries in the distribution process - the duty to assess the basic suitability of at least the financial products offered together with credit for the individual consumer in the light of his or her personal needs and circumstances. After all, even if a proper borrower-focused creditworthiness assessment has been conducted, the consumer may still suffer significant detriment resulting from the purchase of a credit-related product, such as payment protection insurance. This may be the case if the consumer has been pushed into buying the financial product that he or she does not really need or cannot benefit from.

Obviously, the above analysis provides only the main building blocks of the legal framework for responsible consumer credit lending. The suggested minimum core obligations of creditors and credit intermediaries to act responsibly towards consumers when designing and distributing credit or related products need further elaboration. More research is necessary to shed light on how to give more concrete shape to the product governance regime, rules on the consumer's creditworthiness assessment, or basic suitability requirements in the context of consumer credit with due regard to the principles of subsidiarity and proportionality. In particular, identifying the most serious instances of irresponsible lending, their drivers and the best practices for addressing them from across 
the EU could provide useful insight in this respect. Furthermore, the economic analysis of the consumer credit markets could help identify consumer detriment in such markets as well as "toxic" consumer credit products and irresponsible lending practices that may cause it.

As will be shown below, consumer credit lending across the EU may not be entirely in line with the responsible lending obligations of creditors and credit intermediaries as explained above. Areas that are of particular concern include the provision of high-cost credit, crossselling, and peer-to-peer lending (P2PL).

\section{Irresponsible Lending and Its Key Drivers}

\section{General}

While, as has been demonstrated above, responsible lending presupposes that lenders take into account the consumer borrower's interests and needs throughout the relationship between the two, the opposite is true as far as irresponsible lending is concerned. The latter typically occurs when lenders, acting solely in their own interests, design consumer credit and other financial products without due regard to the consumers' interests and needs or distribute such products without performing a thorough borrower-focused creditworthiness assessment or a proper suitability check. What matters to the lenders who act in this way are how much credit risk they would run and how much profit they would make.

Irresponsible lending in the consumer credit markets results first and foremost from what economists describe as "market failures" - that is, "the failure of markets to achieve the economically efficient outcomes with which they are generally associated" (Armour et al. 2016, p. 51). The potential market failures here relate primarily to information asymmetry and behavioural biases in consumer financial decision-making (Armour et al. 2016, pp. 205206). While consumer credit products are typically not easy to understand and evaluate until one has actually "consumed" them, the problem for consumers is made worse by an asymmetry of information between lender and consumer, with the consumer in general being less well informed about a particular credit or related product than the lender. In addition, consumers who are borrowing money will generally not be able to afford financial advice. As a result, consumer borrowers are particularly vulnerable to irresponsible lenders offering financial products that are not as good as they are claimed to be or as appropriate for an individual borrower as other products available on the market. What is more, the consumers' ability to make rational borrowing decisions may be seriously impaired by behavioural biases, such as overoptimism (overestimating one's ability to maintain a zero balance on one's credit card or otherwise repay a loan without incurring undue financial hardship), instantaneous gratification (foregoing a future benefit in order to obtain a less rewarding but more immediate benefit from a more expensive and/or risky loan), myopia (overvaluing the short term-benefits of a credit transaction at the expense of the future), and cumulative cost neglect (neglecting the cumulative effect of a large number of relatively small borrowing choices) (Bar-Gill 2008a; Block-Lieb and Janger 2006; Harris \& Laibson 2013; Ramsay 2005). Consumers, who are younger or older, less wealthy, less well-educated, and/or already heavily indebted, are statistically more likely to make mistakes (Armour et al. 2016, p. 222). The rational response of lenders to irrational preferences of consumers is often not to seek to correct them, but to pander to them (Armour 
et al. 2016, pp. 61, 222). Financial incentives may lead lenders to deliberately design a consumer credit product in such a way as to exploit consumer ignorance or biases or resort to irresponsible lending practices to that effect, causing inefficient market outcomes.

Information asymmetry between lenders and consumers and the systematic exploitation of consumer behavioural biases by financial institutions provide justifications for regulatory interventions vis-à-vis consumers. Such interventions are generally deemed necessary in order to correct the abovementioned market failures (Armour et al. 2016, p. 206; Grundmann 2016, p. 239) and thus protect consumers against irresponsible lending. However, the regulation itself may fail to do so. The regulatory failure is generally associated with poor performance in discharging the core tasks of regulation (Baldwin et al. 2012, pp. 69-72). The latter include, in particular, detecting undesirable behaviour, developing responses and intervention tools to deal with it, and enforcing regulatory rules on the ground. Thus, for example, the failure to detect irresponsible lending may result in under-regulation whereby the undesirable lending behaviour that should be controlled is allowed to escape the constraints of regulation. Alternatively, the regulatory instrument designed to change such behaviour may fail to achieve desired outcomes due to enforcement failings. A common manifestation of such failings may be the prevalence of creative compliance - that is, the practice of side-stepping rules without formally infringing them.

The following analysis will show that irresponsible lending in the consumer credit markets is driven by a combination of market and regulatory failures, in particular when it comes to the provision of high-cost credit, cross-selling, and peer-to-peer lending (P2PL).

\section{The Provision of High-Cost Credit}

Irresponsible lending associated with high-cost credit products poses major risks to consumers (European Parliament 2014, p. 54). This is particularly the case in those segments of the market where small amounts of credit are at stake and/or the costs of credit are much higher than the average. The high costs of a credit product may result from a variety of sources, including but not limited to the basic interest, costs involved in the conclusion of a credit agreement, charges or penalties triggered by non- or late repayment of loans, and fees for going overdrawn. The consumer problems associated with high-cost credit products are twofold. In the first place, the costs in themselves can be excessive, undermining the consumer's payment capacity and making the consumer more vulnerable to unexpected financial difficulties. As a result, consumers run a greater risk of getting into a problematic repayment situation. In addition, once a consumer is not able to repay the agreed amount on time, his or her financial situation is likely to become worse, since high-cost credit usually becomes more expensive over time. As a consequence, the consumer may be forced to take out more credit, often at an excessive rate, to repay the initial debt and/or to cover his or her essential living expenses. By pushing repayments further into the future, the consumer risks become trapped in a spiral of debt.

While the high-cost credit products in themselves may be problematic, poor creditworthiness assessments and the lack of basic suitability checks in the distribution process exacerbate the risk of consumer detriment. This is especially true once small amounts of high-cost credit are at stake, as evidenced by the experiences with payday loans and credit cards which caused much consumer detriment across the EU. These two credit products, which will be considered in more detail below, are typically quite easy to obtain for consumers and generally involve 
high costs. Irresponsible lending in these segments of the consumer credit markets has largely been caused by the market failures related to information asymmetry between lenders and consumers and the widespread manipulation of consumer behavioural biases by credit providers, as well as the regulatory failure to correct these market failures.

\section{Payday Loans}

A payday loan is a relatively small, high-cost instalment loan that has to be repaid over a short term, or until payday. Given these characteristics, it can be categorized as a high-cost shortterm credit. For some time, payday loans have been offered in many EU countries and have been associated with quick and easy access to credit. Some payday loan customers are consumers who tend to prefer payday loans for these very reasons and who thus generally do not consider other credit products to be a close substitute even if they are cheaper. ${ }^{14}$ Notably, the well-known British payday lender Wonga, which went bankrupt in 2018 following a wave of customer compensation claims (Collinson and Jones 2018), used to state on its website that it would "send the cash within five minutes of approval" (Wonga 2018). In addition, many payday loan customers are consumers who do not have credit alternatives available to them when taking out a payday loan. ${ }^{15}$ It is therefore not surprising that payday loans have raised major concerns about their potential to negatively impact the consumers' financial health.

In the UK, for example, the average amount borrowed in 2013 was between GBP 265 and GBP 270 and the payback period was usually a month (Office of Fair Trading 2013, p. 9). On an annual basis, the interest rate could, however, go up to $5,853 \% .{ }^{16}$ In the Netherlands, where a payday loan is known as "flash credit" (flitskrediet), the average amount borrowed in 2011 was EUR 200 and the annual percentage rate of charge (APRC), including but not limited to the annual interest rate, could go up to several hundred percent (Autoriteit Financiële Markten 2014). In Finland, consumers were charged an annual interest of nearly $1,000 \%$ on average (European Parliament 2014, p. 58). Similar products with very high interest rates were also offered to consumers in many Central and Eastern European countries, in particular Estonia, Czech Republic, Slovakia, Slovenia, Poland, and Romania (Reifner et al. 2010, p. 124). The provision of products similar to payday loans, also known as easy credit, by non-banking financial institutions has been reported to cause consumer detriment in Bulgaria and Poland to date. $^{17}$

Apart from excessive interest rates associated with payday loans, a consumer who does not repay the initial debt on time is often confronted with high additional costs. In the UK, for example, one lender charged GBP 179 on average in the 35 days after a missed payment, which included an initial missed payment fee, a further non-payment fee after seven days, a default fee after 35 days, and additional charges for issuing debt collection letters (Office of Fair Trading 2013, p. 24). This shows that payday loans might be suited for consumers who have suffered an unexpected financial setback and need immediate funds, but not for consumers who already find themselves in a problematic repayment situation (cf. Fejõs 2015, p. 187). In the absence of a proper borrower-focused creditworthiness check, however, these products, as

\footnotetext{
${ }^{14}$ On the UK, see, e.g., Competition and Markets Authority (2015, p. 10).

${ }^{15}$ On the UK, see, e.g., Competition and Markets Authority (2015, p. 10).

${ }^{16}$ See Fejõs (2015), who refers to ASA Adjudication on WDFC UK ltd t/a Wonga, 9 April 2014.

${ }^{17}$ Interviews with the representatives of the Bulgarian Ministry of Economy and the Polish Office of Competition and Consumer Protection, respectively.
} 
opposed to most other consumer credit products, are highly accessible for the latter group of consumers. Moreover, the growing digitalization in this segment of the market, which makes it possible, for example, to obtain a payday loan over the Internet or via SMS, further facilitates easy access to this type of high-cost credit (cf. International Financial Consumer Protection Organisation 2017). Notably, in the UK, in 2012-2013, 83\% of payday loan customers took out a loan online, while only $29 \%$ of customers took a payday loan on the high street (Competition and Markets Authority 2015, p. 3). ${ }^{18}$ What is more, the average amount borrowed online (GBP 290) was significantly higher than that borrowed on the high street (GBP 180) (Competition and Markets Authority 2015, p. 3).

Furthermore, a consumer who is not able to repay the initial payday loan on time can easily obtain a new one in order to refinance the previous one. This makes it possible for a payday loan to roll over a number of times. Yet again, the UK provides some telling examples. According to the Competition and Markets Authority (CMA), consumers' demand for payday loans is typically recurring (Competition and Markets Authority 2015, p. 5). In particular, the CMA's analysis suggests that around three-quarters of consumers take out more than one loan in a year, and that on average a customer takes out around six loans per year (Competition and Markets Authority 2015, p. 5). What is more, in 2013 the UK's Office of Fair Trading (OFT), which had responsibility for consumer credit regulation until 1 April 2014 when the UK's FCA took it over, reported a case of a payday loan rolling over 36 times (Office of Fair Trading 2013 , p. 23). The possibility to roll over an existing payday loan thus forms an important feature of this credit product. With every new rollover, new costs are added to the outstanding debt. The consumer thus borrows more and more money, while the amount of money that ultimately benefits him or her remains relatively small.

Similar problems surround the provision of payday loans in many other Member States. Many consumers across the EU resort to payday loans when they are already heavily overindebted and when the only way to escape from their financial trap is to sell some of their assets (such as a car) or enter into a formal debt reduction process (such as bankruptcy) (European Parliament 2014, p. 60). In the Czech Republic, Slovakia, Slovenia, Ireland, Romania, and Poland, this type of product was often used by consumers to cover the fees and charges incurred from prior loan default, with a spiral of increased overindebtedness as a result (Reifner et al. 2010, p. 124). Payday loans can thus be especially harmful to consumers who already have serious debt problems. In particular, this type of credit product presents major problems when it is provided to low-income groups and young people (European Parliament 2014, p. 59).

Irresponsible lending in the payday loan markets has been driven by the market failures and the regulatory failures to correct them. First, given the information asymmetry between payday lenders and consumer borrowers, the latter may not understand the terms and conditions on which the loans are advanced (Armour et al. 2016, p. 263). In addition, the quick and easy access to payday loans emphasized by their providers may be particularly appealing to consumers with a bias towards instantaneous gratification (Armour et al. 2016, p. 263). Such consumers overemphasize the benefits of immediate payoffs without the need to undergo an invasive scrutiny of their finances associated with ordinary bank loans. As a consequence, they tend to use payday loans as a general form of credit to finance ongoing lifestyle expenses and not simply to meet unexpected liquidity needs, further reducing their already limited resources. The result is that the consumers often find it difficult to repay an initial loan and end up in a

$\overline{18}$ There is some overlap, with $12 \%$ of consumers having used both channels. 
cycle of rollovers, reborrowing, and paying further fees and interest each month. Payday lenders tend to contribute to this situation by exploiting consumer ignorance and behavioural biases. In particular, as rollover practices are highly profitable for creditors, the latter have little incentive to perform an adequate assessment of the consumer's creditworthiness before a loan is granted or rolled over. Notably, the UK's OFT concluded in 2013 that rollover practices in this country provided $50 \%$ of lenders' revenues and that $19 \%$ of revenues came from the $5 \%$ of loans which were rolled over or refinanced four or more times (Office of Fair Trading 2013, p. 2). It is therefore not surprising that most payday lenders did not conduct a proper creditworthiness check, and, even worse, that consumers already experiencing repayment problems were advised to take out more loans (Office of Fair Trading 2013, p. 10). As a result, around one-third of the loans were repaid late or not repaid at all, and another $28 \%$ of the loans were rolled over or refinanced at least once (Office of Fair Trading 2013, p. 2).

The extent of irresponsible lending in the payday loan markets has also exposed the regulatory failure to combat the abovementioned practices and prevent consumer detriment at Member State level. One of the major causes of this failure appears to be the lack of sufficiently clear and binding rules on how the consumer's creditworthiness must be assessed, resulting in a wide margin of discretion for lenders and creative compliance. In Bulgaria, for example, relevant consumer credit legislation only imposes on creditors a general obligation to assess the consumers' creditworthiness on the basis of sufficient information prior to the conclusion of a credit agreement. ${ }^{19}$ Absent more concrete standards on how such an assessment should be performed, this broadly formulated provision has not proved itself an effective tool for combating irresponsible high-cost credit lending. ${ }^{20}$ In the UK, until 2014 only nonmandatory guidance on what constitutes irresponsible lending practices was available for lenders (Office of Fair Trading 2011). ${ }^{21}$ Although the guidance was quite detailed, it failed to ensure that the majority of payday lenders made a sufficient and rigorous creditworthiness assessment (cf. Aldohni 2017). Furthermore, one may question whether proper regulation of the lending process alone could prevent consumer detriment in the payday loan markets.

What is more, in the Member States that have introduced relatively strict responsible lending rules, the regulatory failure to address irresponsible payday lending may be caused by regulatory arbitrage, whereby credit providers from Member States with strict regulations engage in cross-border activities in countries with weaker regulations. This problem has manifested itself, for example, in the Netherlands. ${ }^{22}$ While the existence of strict regulatory requirements for the provision of consumer credit does not make the Netherlands an attractive place for the establishment of a payday loan business, the providers of such loans based in other Member States tend to circumvent these requirements by offering payday loans on the Dutch market via Internet. As a result, Dutch consumers in financial difficulties are tempted to borrow money quickly without being aware of the excessive costs charged to them (Autoriteit Financiële Markten 2017). In response to this problem, a ban on advertising payday loans has recently been introduced in the Netherlands. ${ }^{23}$

\footnotetext{
${ }^{19}$ Consumer Credit Act of 12 May 2010, section 12.

${ }^{20}$ Interview with the representative of the Bulgarian Ministry of Economy.

${ }^{21}$ After the FCA took over the regulation of consumer credit from the OFT in April 2014, the OFT guidance on irresponsible lending was replaced by the FCA rules in Consumer Credit sourcebook (CONC) of a binding nature and its own guidance.

22 Interview with the representative of the Dutch Authority for the Financial Markets.

${ }^{23}$ The Dutch Authority for the Financial Markets introduced it based on the newly adopted art. 56a of the Dutch Market Conduct Supervision Degree (Besluit Gedragstoezicht financiële ondernemingen).
} 


\section{Credit Cards}

A credit card is a form of non-instalment credit which allows the consumer to make use of credit reserve within the agreed limits and period of time without having to repay the outstanding amount in a fixed number of payments. The terms of a credit card agreement may require that the consumer repays a certain percentage of the outstanding amount on a regular basis (e.g., each month) or only pays interest throughout the duration of the contract and repays the total amount borrowed upon expiration of the contract. Credit cards are valued by consumers because of their flexibility, which allows consumers to defer payment and spread its costs over a number of months. At the same time, it has been widely noted that credit card facilities tend to operate to the disadvantage of consumers, in particular because the providers of such facilities tend to exploit consumer behavioural biases (Atamer 2011; Bar-Gill 2008a; Bar-Gill 2008b; Reifner et al. 2010, p. 119; Sunstein 2006). Among such biases are overoptimism, myopia, and cumulative cost neglect.

In the first place, credit card credit is one of the most expensive types of credit in terms of interest rates. In April 2019, for example, on average credit card providers in the Euro area charged an interest rate of $16.66 \%$ to households (European Central Bank 2019a). High interest rates on credit cards have been identified as causing financial distress to consumers in the EU (European Parliament 2014, p. 62). Moreover, in some countries, such as Italy, in case of a delay in credit card payments, providers often dramatically increased interest rates not only on the payments overdue, but also on the residual credit on the card (European Parliament 2014, p. 55).

Furthermore, consumer detriment is often associated with the flexible nature of credit card credit (Financial Conduct Authority 2017b, p. 4). As credit card holders are usually allowed to redraw credit after making minimum payments on their credit card debt for an indefinite period, they have continued access to this expensive credit product. As a result, consumers can accumulate and sustain credit card debt over a long period without having to make a significant effort to get out of it. This may lead to "persistent debt" which, following the UK's FCA, can be defined as a situation where, over a period of 18 months, a consumer pays more in interest, fees, and charges than he or she has repaid of the principal on his or her card balance (Financial Conduct Authority 2017b, p. 5). For example, in the UK - the main contributor to the number of credit cards issued in the EU (European Central Bank 2019b) - in 2014, 6.6\% of cardholders (about 2.1 million) were in persistent debt (Financial Conduct Authority 2016, p. 29) and around 650.000 cardholders have been in this situation for at least three consecutive years (Financial Conduct Authority 2016, p. 48). A further 1.6 million cardholders were repeatedly making only minimum payments on their credit card debt, while also incurring interest charges, and 750,000 cardholders have been doing this for at least three consecutive years (Financial Conduct Authority 2016, p. 48). Given that credit cards are suited for shortterm borrowing, the FCA expressed its concerns about the volume of borrowing behaviour in the UK that does not fit this pattern. According to this authority:

"Using credit cards to service long-term debt (as opposed to benefitting from the flexibility that rolling credit offers in the short term) tends to be expensive and these consumers may be paying more than they need to in debt service costs; struggling under a debt burden; or storing risk that, in case of a life event (e.g., sickness or unemployment) may become problematic" (Financial Conduct Authority 2016, p. 48).

Consumers who have persistent credit card debt or only make systematic minimum repayments on their card without making significant contributions to repaying the outstanding 
balance tend to be highly profitable for creditors. The "sweatbox" model of credit card lending described by Mann is a case in point. In this model, "the most profitable consumers are sometimes the least likely to ever repay their debts in full" (Mann 2007, p. 384). Therefore, creditors have an incentive to keep consumers in the sweatbox rather than intervene to address the consumers' lending behaviour and help them to reduce debt burdens as quickly as they can. As a result, in the absence of effective regulatory intervention to correct the market failure related to the misuse of consumer behavioural biases, spending on a credit card can easily get out of control and cause consumer detriment. It is questionable, however, to what extent general rules on the provision of consumer credit, in particular that on creditworthiness assessments, are capable of combating the above mentioned irresponsible credit card lending practices.

\section{Cross-Selling}

Irresponsible lending across the EU is also associated with cross-selling. In the present context, cross-selling, also known as product bundling, refers to the practice of selling a credit product together with another financial product, such as insurance. Cross-selling can take the form of a tying practice, meaning that another financial product is made mandatory to obtain a loan from a given provider. Alternatively, such a product can be offered to consumers as an optional extra (cf. International Financial Consumer Protection Organisation (FinCoNet) 2017, p. 31). Crossselling of financial products can result in a situation where consumers purchase products that they do not necessarily want or need and that entail additional fees and charges.

Cross-selling has been identified as a problematic selling practice in a large number of Member States (European Banking Authority 2017, p. 22). The examples include the provision of a loan in combination with payment protection insurance (PPI), car insurance, or life insurance, where consumers did not need the insurance or were unaware that they were taking it out when concluding a credit agreement (European Banking Authority 2017, p. 22). The tying of credit cards to other products has also been an issue. For example, in the Czech Republic many consumers were unknowingly issued a credit card the moment they were purchasing other products (European Parliament 2014, p. 62). In this example, the consumers might be tempted to use the credit card and, as a consequence, may end up in a problematic repayment situation.

Cross-selling of PPI deserves special attention in this context. PPI is an insurance policy that enables consumers to insure repayment of loans if the borrower dies, becomes ill or disabled, or faces other circumstances preventing him or her from meeting the obligations under a credit agreement. As with any other type of insurance, PPI may exclude or impose restrictive conditions on particular types of claimant (e.g., self-employed or contract workers) or claim (e.g., sickness related to preexisting medical condition) and may be subject to other terms that limit the cover provided.

In the UK, for example, the cross-selling of PPI - mortgage PPI, personal loan PPI, and credit card PPI (Competition Commission 2009, p. 22) - has resulted in the largest mis-selling scandal in its financial history (European Parliament 2014, p. 69). ${ }^{24}$ As of March 2019, GBP 34.9 billion was set aside by financial firms for compensation payouts (Financial Conduct Authority 2019). The scandal has revealed two major problematic aspects of the selling process (Financial Services Authority 2006; Financial Services Authority 2007; Financial

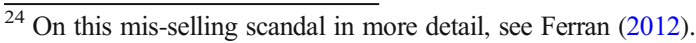


Services Authority 2008). First of all, many consumers were provided with inadequate information about the benefits, exclusions, limitations, and costs of such policies. In addition, while the standard features of such products imply a suitability risk, in many cases no adequate suitability checks were performed. As a consequence, many consumers bought products that were wholly unsuitable for them because from the very outset they did not meet eligibility requirements under the product terms to be able to make a claim.

Similar problems with the cross-selling of PPI have been reported in other parts of Europe (European Parliament 2014, p. 128). In Spain, for example, some consumers who bought PPI were misled to believe that they were protected in case of unemployment or temporary incapacity. In Ireland, firms gathered insufficient information on consumers in order to be able to ensure the suitability of PPI for each client. As of May 2012, refunds announced by the Irish banks exceeded EUR 4 million. Germany has also been profoundly affected by the misselling of PPI. While consumers who took out a loan from a given bank were not contractually obliged to purchase PPI, subprime borrowers were in practice led to believe that this was indeed the case (Bundesanstalt für Finanzdienstleistungsaufsicht 2017, p. 31). Moreover, borrowers were often charged high insurance premiums, which pushed up the total cost of a loan (Reifner 2017).

Irresponsible cross-selling has been driven by the same market failures that have manifested themselves in the context of high-cost credit - information asymmetry between creditors and credit intermediaries, on the one hand, and consumers, on the other, as well as the widespread exploitation of consumer behavioural biases by credit providers. The lack of consumer understanding of PPI terms has played a particular role in this context. Being motivated by remuneration arrangements that award volume-based sales, however, creditors and credit intermediaries have lacked sufficient incentives to correct irrational consumer preferences and adequately inform consumers about the product terms (cf. European Parliament 2014, p. 62).

The issue of commissions payable to creditors and credit intermediaries by third parties deserves special mention here. Selling PPI has proved to be a highly profitable business, in particular as a result of such commissions. In the UK, for example, the commissions payable to loan brokers were typically between $50 \%$ and $80 \%$ of gross written premium for policies sold in connection with a personal loan (Competition Commission 2009, p. 2). Notably, these levels of commission were much higher than those payable for introducing the loan itself, which meant that a large proportion of the profits of loan brokers was derived from selling PPI policies. It is therefore not surprising that many consumers were even pressured into buying such policies (e.g., Osborne 2008). Similarly, in Germany, the commissions paid by insurance companies to credit institutions for selling PPI together with a personal loan were sometimes extremely high, in some cases amounting to $50 \%$ or more of insurance premium (Bundesanstalt für Finanzdienstleistungsaufsicht, pp. 19, 33).

The scale of the problem associated with the irresponsible cross-selling of PPI in many EU Member States points to pervasive regulatory failure. The latter has manifested itself, inter alia, in the uncertainty about and non-compliance with the applicable legal standards, in particular concerning the provision of information and advice, as well as the absence of more protective rules, such as the lenders' duties to ensure the suitability of financial products offered together with credit for consumers. In addition, the problem has been exacerbated by the lack of effective regulatory measures targeting remuneration structures that have considerable potential to misalign incentives between lenders and consumers. Interestingly, the UK, which was particularly badly hit by the mis-selling of PPI, has recently adopted new rules on staff 
incentives in consumer credit that require firms to identify and manage risks arising from remuneration or performance management practices. ${ }^{25}$ These rules, however, do not apply to firm-to-firm commercial remuneration and commission arrangements (Financial Conduct Authority (2018b).

\section{Peer-to-Peer Lending}

As the regulatory grip on the traditional financial sector has tightened post-crisis, novel forms of financial contracting outside it have emerged, such as crowdfunding. The latter connects those who give, lend, or invest money directly with those who need financing. P2PL, also known as debt-based or lending-based crowdfunding, accounts for the largest share of this emerging market (European Commission 2017c, p. 1), with peer-to-peer consumer lending being its biggest segment (Zhang et al. 2016a, p. 20). In general terms, P2PL can be defined as "the use of an electronic platform that matches lenders/investors with borrowers/issuers in order to provide unsecured loans, including consumer lending, as well as lending against real estate" (International Financial Consumer Protection Organisation 2017, p. 20). These services are usually provided by new market entrants known for the heavy digitalization of their processes, including technological support for credit analysis and payment settlements.

The P2PL model entails benefits for consumers in terms of convenience. It also offers improved access to credit for consumers who cannot obtain it from conventional lenders. At the same time, P2PL also poses major risks to all the parties involved - that is, consumer lenders, consumer borrowers, and platform operators (European Banking Authority 2015a). In the present context, the risks to consumer lenders and borrowers who use the services of a platform deserve special attention. Consumer lenders may lose the amount borrowed following either the consumer borrower's or the platform's default (European Banking Authority 2015a, pp. 2-14; Macchiavello 2017). They may also be unaware of such risks, relying on misleading advertisements or unverified information, in particular about the consumer borrower and his or her project. It is notable that current data reveal an increase in defaults and business failures in the P2PL markets (Zhang et al. 2016a, p. 47; Zhang et al. 2016b, p. 34). Importantly, in responding to a sector survey, the platforms have identified their own malpractice and borrowers' defaults/failures as the main current risks in Europe (Zhang et al. 2016a, p. 47; Zhang et al. 2016b, p. 34). Absent a proper assessment of their creditworthiness, consumer borrowers, in turn, may end up in a problematic repayment situation (European Banking Authority 2015a, pp. 16, 20; International Financial Consumer Protection Organisation 2017, p. 21).

Therefore, in contrast to the traditional financial sector where irresponsible lending practices may only affect consumer borrowers, both consumer lenders and consumer borrowers can become a victim of such practices in the case of P2PL. Although the P2PL is presented as a form of democratic, participating, and disintermediated finance, consumer lenders and consumer borrowers need a P2PL platform in order to reduce information asymmetries between them. It is questionable, however, whether the market will be able to correct itself without regulatory intervention (cf. Macchiavello 2017, p. 673). The way in which such platforms currently operate raises serious concerns about their reliability in this respect. It also casts doubt on the appropriateness of the existing national legal regimes applicable to P2PL and their effectiveness in protecting consumers against risks posed by it.

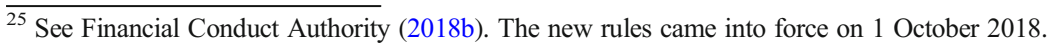




\section{The Limitations of the 2008 Consumer Credit Directive}

\section{General}

As mentioned above, the 2008 Consumer Credit Directive is based on the information model of consumer protection. The latter is reflected in the extensive information requirements to be complied with by creditors or credit intermediaries throughout the relationship with consumers. ${ }^{26}$ The provision of information should enable a reasonably observant and circumspect consumer ${ }^{27}$ to reap the benefits of the European consumer credit markets, empowering him or her to make a reasonable choice among credit products. It is noteworthy that a number of more protective rules contained in the European Commission's proposal for the directive in question $^{28}$ were ultimately dropped during the legislative process. These included the duty of "responsible lending," ${ }^{29}$ specific rules on unfair terms in a consumer credit agreement, ${ }^{30}$ and the rights and obligations of the parties in the event of a debtor's non-performance of such an agreement. ${ }^{31}$ Furthermore, no new attempt was made to harmonize usury laws at EU level (Commission of the European Communities 1995). Such more intrusive regulation was considered to be incompatible with the idea of "consumer credit as lubricant" and the corresponding need to foster increased access to credit for European consumers (Ramsay 2016, p. 162) which dominated the policy discourse until the outbreak of the global financial crisis.

However, the persistent irresponsible lending practices across the EU and widespread regulatory failures to prevent them at Member State level identified above cast serious doubt about the extent to which the 2008 Consumer Credit Directive's image of the average European consumer is sufficiently grounded in the reality of consumer borrower decisionmaking and about whether this directive itself is well-equipped to deal with such practices. In the following, therefore, a closer look will be taken at the Consumer Credit Directive's approach to harmonization of consumer protection standards, with a particular focus on the provision of high-cost credit, cross-selling, and P2PL. It will be discussed in the context of the applicable horizontal EU instruments, notably the Unfair Contract Terms Directive and the Unfair Commercial Practices Directive, as well as the case law of the Court of Justice of the European Union (CJEU). Where relevant, a comparison will be drawn with other EU measures in the field of retail financial services, in particular the Mortgage Credit Directive ${ }^{32}$ and the Markets in Financial Instruments Directive II (MiFID II) ${ }^{33}$ adopted in the aftermath of the

\footnotetext{
${ }^{26}$ Consumer Credit Directive, arts 4-6, 10-12, 18, 21.

${ }^{27}$ Cf., e.g., CJEU C-210/96 Gut Springenheide and Rudolf Rusky v. Oberkreisdirektor des Kreises Steinfurt, ECLI:EU:C:1998:369, paras 30-31.

${ }^{28}$ Commission of the European Communities, Proposal for a Directive of the European Parliament and of the Council on the harmonization of the laws, regulations and administrative provisions of the Member States concerning credit for consumers, $\operatorname{COM}(2002) 443$ final.

${ }^{29}$ Ibid., art. 9.

30 Ibid., art. 15.

31 Ibid., arts 24-27.

32 Directive 2014/17/EU of the European Parliament and of the Council of 4 February 2014 on credit agreements for consumers relating to residential immovable property and amending Directives 2008/48/EC and 2013/36/EU and Regulation (EU) No 1093/2010 (2014) OJEU L 60/34 (Mortgage Credit Directive). Notably, this directive refers to the congruence of its provisions with the G20 high-level principles of financial consumer protection developed by the OECF in the wake of the global financial crisis (Mortgage Credit Directive, recital 3).

${ }^{33}$ Directive 2014/65/EU of the European Parliament and of the Council of 15 May 2014 on markets in financial instruments and amending Directive 2002/92/EC and Directive 2011/61/EU (2014) OJEU L 173/349 (MiFID II).
} 
financial crisis. Some enforcement-related issues that give rise to concern in the context of consumer credit will also be discussed.

\section{Consumer Protection Standards}

\section{The Provision of High-Cost Credit}

The analysis of the Consumer Credit Directive reveals several major limitations of this directive in protecting consumers against the mis-selling of high-cost credit products. First of all, the directive is not applicable to loans involving a total amount of credit less than EUR 200. The payday loans below this amount thus fall within the exclusive competence of the Member States. As shown above, however, regardless of the amount of money involved, small payday loans may cause significant consumer detriment due to the excessively high interest rates and unlimited rollovers.

Second, while poor creditworthiness checks, particularly when selling high-cost credit products, have been one of the major causes of consumer detriment across the EU, Article 8 of the Consumer Credit Directive imposes only a modest obligation on the creditor to assess the consumer's creditworthiness before the conclusion of the credit agreement or any significant increase in the amount of credit afterwards. The weaknesses of this provision manifest themselves at each of the three steps of the creditworthiness assessment process identified above: (1) obtaining relevant information about the consumer's financial situation, (2) judging the consumer's creditworthiness, and (3) deciding on the consumer's credit application.

Step 1. Obtaining relevant information about the consumer's financial situation.

Article 8 of the Consumer Credit Directive makes clear that the creditworthiness assessment should be based on the "sufficient information" obtained from the consumer and/or the relevant database. According to the CJEU, "the sufficient nature of the information may vary depending on the circumstances in which the credit agreement was concluded, the personal situation of the consumer or the amount covered by the agreement." ${ }^{34}$ In the light of this, the Court also ruled that Article 8 allows the creditor to assess the consumer's creditworthiness solely on the basis of information supplied by the consumer, provided that that information is sufficient and that mere declarations by the consumer are also accompanied by supporting evidence. ${ }^{35}$ Furthermore, this provision does not require the creditor to systematically verify the information supplied by the consumer. ${ }^{36}$

The Consumer Credit Directive as interpreted by the CJEU thus leaves much leeway to the Member States when it comes to gathering information about the consumer's financial situation. It is therefore not surprising that creditworthiness assessments in the field of consumer credit are carried out in ways that differ significantly across the EU (European Commission 2017a, para. 3.2). Given the widespread problems in the high-cost credit markets, however, it is questionable to what extent current national rules governing the collection of

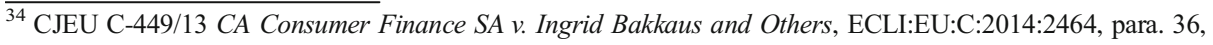
para. 37.

${ }^{35}$ Ibid., para. 39.

${ }^{36}$ Ibid., para. 39. 
information for the purposes of such assessments in many Member States can effectively prevent irresponsible lending.

It is notable that the Mortgage Credit Directive has adopted a more prescriptive approach to information collection for the purposes of the consumer's creditworthiness assessment before concluding a mortgage contract. This directive specifies that such an assessment should be carried out "on the basis of information on the consumer's income and expenses and other financial and economic circumstances which is necessary, sufficient and proportionate." 37 The directive also requires that the creditor obtains such information "from relevant internal or external sources, including the consumer, and including information provided to the credit intermediary or appointed representative during the credit application process," and that it appropriately verifies this information. ${ }^{38}$ Moreover, these requirements are further specified in the guidelines of the European Banking Authority (EBA) (European Banking Authority 2015b).

\section{Step 2. Judging the consumer's creditworthiness.}

Once the creditor has collected the necessary data, it makes a judgement about the consumer's creditworthiness. As has been shown above, responsible lending can only be ensured if the creditor does not only conduct a creditor-focused assessment, but also the borrower-focused test. The latter underlines a potential conflict of interests between creditors and consumer borrowers, particularly when it comes to high-cost credit. As the above analysis of the irresponsible lending practices in the payday loan and credit card markets has shown, creditors can engage in a cycle of extending credit and generating profit from consumers who pay interest and penalty charges at a sufficient level to make the loan profitable regardless of whether it is eventually repaid.

However, the wording of Article 8 of the Consumer Credit Directive does not make clear what kind of creditworthiness test - creditor-focused or borrower-focused - is envisaged by it. As a result, the adopted solutions vary greatly across the EU. The UK, for example, has explicitly opted for a borrower-focused test (Financial Conduct Authority 2017a). The Consumer Credit Sourcebook currently in force explicitly requires that, in making the creditworthiness assessment, financial firms "take into account more than assessing the customer's ability to repay the credit" 39 and take reasonable steps "to assess the customer's ability to meet repayments under a regulated credit agreement in a sustainable manner without the customer incurring financial difficulties or experiencing significant adverse consequences. " the borrower-focused test has, in essence, been adopted in the Netherlands (Cherednychenko and Meindertsma 2014). The basic rule is that when providing simple consumer credit, financial institutions should act as responsible creditors with a view to preventing consumer overindebtedness; for this purpose, before concluding a credit agreement, they should obtain information concerning the consumer's financial position in the best interests of the consumer and assess whether providing credit to him or her is justified. ${ }^{41}$ The content of this general obligation to lend in a responsible way is further specified in the codes of conduct of the branch organizations which are considered by the Dutch Authority for the Financial Markets to

\footnotetext{
$\overline{37}$ Mortgage Credit Directive, art. $20(1)$.

38 Ibid.

${ }^{39}$ FCA Consumer Credit Sourcebook, para. 5.3.1 (1).

${ }^{40}$ FCA Consumer Credit Sourcebook, para. 5.3.1 (2) (emphasis added).

${ }^{41}$ Financial Supervision Act 2006 (Wet op het financieel toezicht (Wft) 2006), art. 4:34(1).
} 
lay down minimum rules on responsible lending for different types of credit. The starting point for assessing whether the provision of consumer credit is justified is that upon incurring interest- and repayment-related obligations under the credit agreement, the consumer still has the means to provide for his or her basic needs and to bear his or her recurring expenses. ${ }^{42}$ If this is not the case, providing credit would be considered irresponsible. In contrast, in Greece, where the relevant provisions of national law closely follow the wording of Article 8 of the Consumer Credit Directive, it is not entirely clear what kind of creditworthiness test - creditorfocused or borrower-focused - has been envisaged (Livada 2016). A similar situation reportedly exists in Bulgaria. ${ }^{43}$

By way of comparison, the Mortgage Credit Directive as elaborated by EBA suggests a borrower-focused test. In particular, the directive explicitly states that the creditworthiness test cannot rely predominantly on the fact that the value of the property exceeds the amount of the credit or the assumption that the property will increase in value, unless the purpose of the credit agreement is to construct or renovate the property. ${ }^{44}$ In addition, when making the judgement about the creditworthiness, the creditor "should make reasonable allowances for committed and other non-discretionary expenditures such as the consumers' actual obligations, including appropriate substantiation and consideration of the living expenses of the consumer" (European Banking Authority 2015b, guideline 5.1). What is more, the creditor should even "make prudent allowances for potential negative scenarios in the future, including for example, a reduced income in retirement; an increase in benchmark interest rates in the case of variable rate mortgages; negative amortisation; balloon payments, or deferred payments of principal or interest" (European Banking Authority 2015b, guideline 6.1).

Step 3. Deciding on the consumer's credit application.

After having made a judgement about the consumer's creditworthiness, the creditor can decide on the consumer's credit application. According to the CJEU, Article 8 of the Consumer Credit Directive "aims to make creditors accountable and to avoid loans being granted to consumers who are not creditworthy." 45 However, this provision does not address the issue of what the creditor should do in case of the negative outcome of the creditworthiness test. At present, the solutions adopted at the national level differ across the EU. While some Member States, such as Belgium, ${ }^{46}$ Germany, ${ }^{47}$ and the Netherlands, ${ }^{48}$ have introduced an explicit statutory prohibition on granting credit in such a case, other Member States, such as the UK, have not gone that far in the area of unsecured consumer credit. Furthermore, in some Member States, notably Bulgaria, ${ }^{49}$ Poland, ${ }^{50}$ Greece (Livada 2016), and Italy (Cerini 2016), the issue in question has reportedly not been addressed at all.

\footnotetext{
${ }^{42}$ See, for example, the Consumer Credit Code of Conduct of the Dutch Banking Association (Gedragscode Consumptief Krediet van de Nederlandse Vereniging van Banken (NVB) (effective as of 1 January 2012), arts 5 and 6.

${ }^{43}$ Interview with the representative of the Bulgarian Ministry of Economy.

${ }^{44}$ Mortgage Credit Directive, art. 18(3) and recital 55.

${ }^{45}$ CJEU C-449/13 CA Consumer Finance SA v. Ingrid Bakkaus and Others, ECLI:EU:C:2014:2464, para. 35, with reference to Consumer Credit Directive, recital 26.

${ }^{46}$ Code of Economic Law (Wetboek van economisch recht), art. VII.77(2).

${ }^{47}$ German Civil Code (Bürgerliches Gesetzbuch $(B G B)$ ), § 505a(3).

${ }^{48}$ Financial Supervision Act 2006 (Wet financieel toezicht 2006), art. 4:34(2).

${ }^{49}$ Interview with the representative of the Bulgarian Ministry of Economy.

${ }^{50}$ Interview with the representative of the Polish Office of Competition and Consumer Protection.
} 
While the Consumer Credit Directive does not preclude Member States from adopting stricter rules in case of the negative outcome of the consumer's creditworthiness test (such as a duty to warn or a duty to deny credit), ${ }^{51}$ the only obligation under EU law which currently rests upon the creditor in such a case is a duty to provide the consumer with "adequate explanations" in good time before signing the credit agreement. ${ }^{52}$ Such explanations should "place the consumer in a position enabling him to assess whether the proposed credit agreement is adapted to his needs and to his financial situation." 53 It is questionable, however, whether the duty to provide adequate explanations alone can effectively prevent consumer detriment in increasingly digital high-cost credit markets where the consumers' ability to make rational borrowing decisions is often seriously impaired by behavioural biases.

By contrast with the Consumer Credit Directive, the Mortgage Credit Directive explicitly obliges the creditor to refuse granting credit to the consumer in case of the negative result of the creditworthiness test. This duty follows from the positively formulated provision of this directive under which "the creditor only makes the credit available to the consumer where the result of the creditworthiness assessment indicates that the obligations resulting from the credit agreement are likely to be met in the manner required under that agreement." 54

Third, the Consumer Credit Directive does not provide any substantive safeguards against excessively high interest rates or other potentially dangerous features of high-cost credit products that may adversely affect the consumer's financial health. In particular, the directive does not require that Member States regulate product contract terms in the form of price caps or rollover restrictions. Neither does it lay down any rules designed to prevent financial institutions developing financial products that may cause consumer detriment. In the absence of EU harmonization on such sensitive issues, it is up to Member States how to deal with them and the adopted solutions vary greatly (e.g., Cherednychenko 2014; Reifner et al. 2010). Following the persistent irresponsible lending in the payday loan markets, the UK's FCA, for example, has intervened into the substance of payday loan contracts by introducing a price cap on interest, fees, and default charges, and restricting the number of times a loan could roll over (Financial Conduct Authority 2014). Similarly, in order to rebalance the credit card firms' incentives to allow consumers to make only minimum repayments on a credit card indefinitely, the UK's FCA recently adopted new rules on the treatment of customers whose credit card debt persists over 18 to 36 months (Financial Conduct Authority 2017b; Financial Conduct Authority 2018a). ${ }^{55}$ Under these rules, financial firms are required to monitor a credit card customer's repayment record and any other relevant information held by the firm, and take appropriate action where there are signs of actual or potential financial difficulties. In

\footnotetext{
${ }^{51}$ See Opinion of A.G. Kokott in Case C-58/18 Michel Schyns v. Belfius Bank NV, ECLI:EU:C:2019:120, para. 79, where the Advocate General of the CJEU has argued that neither Article 5(6) nor Article 8(1) of the Consumer Credit Directive precludes a national rule which allows a creditor to conclude a credit agreement only in case it can reasonably assume that a consumer will be able to meet the obligations resulting therefrom.

52 This follows from the case law of the CJEU on the interpretation of Article 5(6) in conjunction with Article 8 of the Consumer Credit Directive. See CJEU C-449/13 CA Consumer Finance SA v. Ingrid Bakkaus and Others, ECLI:EU:C: 2014:2464, paras 40-49.

${ }_{53}$ Consumer Credit Directive, art. 5(6).

${ }^{54}$ Mortgage Credit Directive, art. 18(5)(a). Despite such protective provisions, the Mortgage Credit Directive has been criticized for a formalistic understanding of a mortgage contract, which manifests itself, in particular, in the failure to address the negative effects of unforeseen circumstances on the consumer's ability to repay the loan. (e.g., Domurath 2016, p. 767).

55 The new rules entered into force on 1 March 2018.
} 
many Member States, however, similar irresponsible lending practices have not prompted any such regulatory action to date.

Yet again, a comparison between the Consumer Credit Directive and the Mortgage Credit Directive reveals a striking difference between the two. The Mortgage Credit Directive makes clear that, when manufacturing or distributing products, creditors and credit intermediaries must act "honestly, fairly, transparently and professionally, taking account of the rights and interests of the consumers." EBA's guidelines on product oversight and governance arrangements for both manufacturers and distributors (European Banking Authority 2016). In particular, such arrangements should be designed to ensure that the interests, objectives, and characteristics of consumers are appropriately taken into account, to avoid potential consumer detriment, and to minimize conflicts of interest (European Banking Authority 2016, guidelines 1.1 and 9.1). Given a lack of the respective legal basis in the Consumer Credit Directive, however, EBA currently has no competence to develop similar guidelines for consumer credit products.

In the absence of specific product-related regulation at EU or national level, consumers may derive some protection against potentially dangerous features of high-cost credit products from the Unfair Contract Terms Directive. In particular, excessive default charges on payday loans and credit cards may fall under its scope. ${ }^{57}$ Notwithstanding the current importance of the Unfair Contract Terms Directive - once the "sleeping beauty" which has been "kissed awake" by the CJEU in the wake of the global financial crisis (Micklitz and Reich 2014, p. 772) - it should be borne in mind that this directive is not applicable to cases in which no unfair preformulated terms are involved. Moreover, the "fairness control" under this directive is not concerned with the substantive fairness of credit transactions, ${ }^{58}$ but rather with the fairness of the procedure that has led to their conclusion. Therefore, the ability of the Unfair Contract Terms Directive to make up for the lack of substantive safeguards against potentially dangerous features of high-cost credit products is inherently limited. ${ }^{59}$

\section{Cross-Selling}

While cross-selling, whereby a consumer credit product is sold together with payment protection insurance or another financial product, has been identified as one of the major causes of consumer detriment in the European consumer credit markets, the 2008 Consumer Credit Directive does not comprehensively deal with this practice. The directive only requires that, where the consumer is obliged to purchase an insurance policy in order to obtain credit, the costs of such a policy should be included in the total cost of credit (that is, APRC) designed to help consumers compare different offers. ${ }^{60}$ However, the Consumer Credit Directive does not impose any restrictions on making the provision of credit conditional on payment protection insurance or another financial product, also known as tying. Nor does it contain

\footnotetext{
${ }^{56}$ Mortgage Credit Directive, art. $7(1)$.

${ }^{57}$ See Unfair Contract Terms Directive, Annex 'Terms Referred to in Article 3 (3),' pont 1 (e). Cf., e.g., CJEU C-415/11 Mohamed Aziz, v. Caixa d'Estalvis de Catalunya, Tarragona i Manresa (Catalunyacaixa), ECLI:EU:C:2013:164, para. 74.

${ }^{58}$ See Unfair Contract Terms Directive, art. 4(2). On the history of this provision, see Opinion of A.G. Trstenjak in Case C-484/08 Caja de Ahorros y Monte de Piedad de Madrid v. Asociación de Usuarios de Servicios Bancarios (Ausbanc), ECLI:EU:C:2009:682, paras 61-66.

${ }^{59}$ In the context of mortgage credit, cf. Domurath (2016).

${ }^{60}$ Consumer Credit Directive, art. 19 and Annex II, para. 3.
} 
rules designed to ensure the basic suitability of credit-related products for individual consumers. Although the Consumer Credit Directive does not preclude Member States from introducing such rules, ${ }^{61}$ it clearly does not oblige them to do so.

By way of comparison, the Mortgage Credit Directive lays down specific rules designed to restrict some cross-selling practices. Importantly, the directive distinguishes between product bundling and product tying. The latter is understood as "the offering or the selling of a credit agreement in a package with other distinct financial products or services where the credit agreement is not made available to the consumer separately." ${ }^{62}$ Whereas bundling practices are allowed, tying practices are generally prohibited. ${ }^{63}$ The idea behind this rule is "to prevent practices such as tying of certain products which may induce consumers to enter into credit agreements which are not in their best interest, without however restricting product bundling which can be beneficial to consumers." 64

In addition, the Mortgage Credit Directive acknowledges that remuneration policies may incentivize creditors and credit intermediaries to conclude a given number or type of credit contracts or offer particular ancillary services to consumers without considering their interests and needs. ${ }^{65}$ The directive, therefore, requires creditors and credit intermediaries to act "honestly, fairly, transparently and professionally, taking account of the rights and interests of the consumers" $" 66$ and to ensure that the manner in which creditors remunerate their staff and appointed representatives does not impede compliance with this obligation. ${ }^{67}$ These provisions leave much leeway to Member States in determining which remuneration practices may harm the interests of consumers and how to tackle such practices. While the effectiveness of national rules to this effect still needs to be proved, the fact that the Mortgage Credit Directive focuses attention on the potential dangers of remuneration practices, such as third-party commissions, is a step in the right direction.

It is also notable that MiFID II obliges investment firms that are offering financial instruments to retail investors on an execution-only basis to assess whether the investment service, product, or bundle of services or products is "appropriate" for the client and warn him or her if this is not the case. ${ }^{68}$ For this purpose, firms should ask retail investors to provide information regarding their relevant knowledge and experience. ${ }^{69}$ Importantly, the "appropriateness" test under MiFID II is considerably less extensive than the "suitability" test which this directive prescribes for the providers of investment advice and portfolio management. ${ }^{70}$

\footnotetext{
${ }^{61}$ See Opinion of A.G. Kokott in Case C-58/18 Michel Schyns v. Belfius Bank NV, ECLI:EU:C:2019:120, para. 61, where the Advocate General of the CJEU has concluded that Article 5(6) of the Consumer Credit Directive does not preclude a national rule which requires a creditor and a credit intermediary to advise a consumer on the most appropriate credit given the consumer's financial situation and the purpose of obtaining credit. Such an obligation goes even further than the lenders' duty to ensure the basic suitability of financial products offered together with credit - one of the minimum requirements for responsible lending advocated by the authors here. ${ }^{62}$ Mortgage Credit Directive, art. 4(26).

${ }^{63}$ Mortgage Credit Directive, art. 12(1). At the same time, the general prohibition of tying practices has been weakened by allowing Member States to introduce exemptions from this rule in a number of situations (art. 12(24)).

${ }^{64}$ Mortgage Credit Directive, recital 24.

${ }^{65}$ Mortgage Credit Directive, recital 35.

${ }^{66}$ Mortgage Credit Directive, art. 7(1).

${ }^{67}$ Mortgage Credit Directive, art. 7(2).

${ }^{68}$ MiFID II, art. 25(3).

69 Ibid

${ }^{70}$ MiFID II, art. 25(2).
} 
In the absence of sector-specific EU or national rules on unfair cross-selling practices related to consumer credit, consumers could derive some protection from the Unfair Commercial Practices Directive and the Unfair Contract Terms Directive. While the Unfair Commercial Practices Directive does not contain a general prohibition of tying practices, such practices might be considered unfair and hence prohibited following a case-by-case assessment (European Commission 2016b, p. 14). In addition, this directive could potentially play a role in combating misleading and aggressive cross-selling practices even in those cases where no tying in involved. ${ }^{71}$ In particular, a failure to include the costs of payment protection insurance in APRC may constitute a misleading commercial practice within the meaning of Article 6(1) of this directive, which, in turn, constitutes one of the elements on which the national court may base its assessment of the unfairness of the contractual terms relating to the cost of the loan granted to the consumer under Article 6(1) of the Unfair Contract Terms Directive. ${ }^{72}$ Yet, it is highly questionable whether these general provisions suffice to ensure adequate consumer protection against unfair cross-selling in the consumer credit markets.

In this context, it is worth mentioning that, in 2014, the Joint Committee of the three European Supervisory Authorities (ESAs) - EBA, the European Insurance and Occupational Pensions Authority (EIOPA), and the European Securities and Markets Authority (ESMA) made an attempt to develop a coherent regulatory approach to cross-selling across the three sectors of banking, insurance, and investments, respectively, in order to ensure consumer protection (Joint Committee of the European Supervisory Authorities 2014). However, this attempt proved unsuccessful due to major inconsistencies across existing legislative instruments (European Banking Authority 2017, p. 22).

\section{Peer-to-Peer Lending}

The drafters of the Consumer Credit Directive designed this legislative instrument with the conventional borrowing model in mind. It applies to credit agreements in which a creditor (that is, a natural or legal person acting in the course of his trade, business of profession) grants or promises to grant credit to a consumer (that is, a natural person who is acting for purposes which are outside his trade, business or profession). ${ }^{73}$ The P2PL model, which connects those who lend money directly to those who need financing by means of an electronic P2PL platform, does not fit into this legal framework and thus falls outside the directive's scope of application. While the lack of a proper assessment of the consumer borrower's creditworthiness assessment may pose major risks in this emerging market, the Consumer Credit Directive would not apply to P2PL platforms given that they typically do not act as lenders in the sense of this directive (cf. European Banking Authority 2015a, p. 31). Neither would the directive apply to consumer lenders as they normally do not grant credit to consumers in the course of their trade, business, or profession.

As the existing EU legislation does not harmonize rules on responsible lending in the area of P2PL, their development is left entirely up to the Member States. At present, the legal regimes for P2PL vary greatly across the EU (e.g., European Banking Authority 2015a, p. 3640; Macchiavello 2017). The UK, for example, has extended its consumer credit regime

\footnotetext{
${ }^{71}$ Unfair Commercial Practices Directive, arts 6-8.

72 Cf., e.g., CJEU C-453/10 Jana Pereničová, Vladislav Perenič v. SOS financ spol. s $r$. o., ECLI:EU:C:2012:144, para. 47.

${ }^{73}$ See Consumer Credit Directive, art. 3 (a)-(c).
} 
to P2PL. As a result, P2PL platforms are required to assess the consumer borrower's creditworthiness. ${ }^{74}$ However, one may question to what extent P2PL platforms should be subject to the same responsible lending duties that apply to traditional lenders. While there are currently many questions about the appropriate regulatory response to the risks posed by P2PL to consumers, consumer P2PL falls outside the scope of the European Commission's recent proposal for a regulation on European crowdfunding service providers (European Commission 2018).

\section{Enforcement}

\section{General}

The previous analysis has shown that despite the CJEU's efforts to expand the underdeveloped concept of responsible lending in the 2008 Consumer Credit Directive, the ability of this directive to tackle most imminent irresponsible lending practices that upset the consumer credit markets in many EU Member States remains inherently limited. The EU measures of a horizontal nature, in particular the Unfair Contract Terms Directive and the Unfair Commercial Practices Directive, cannot adequately compensate for major substantive limitations of the Consumer Credit Directive in combating irresponsible lending in the high-cost credit markets and unfair cross-selling, as well as emerging problems in the field of per-to-peer lending. The degree of consumer protection against such practices thus largely depends on the national consumer credit legislation enacted within the broad framework set out by the Consumer Credit Directive. ${ }^{75}$ Although this directive does not preclude Member States from adopting more protective responsible lending rules than those laid down therein, the effectiveness of the national laws of many Member States must be questioned, given many instances of mis-selling in the consumer credit markets across the EU over the past decade. Member States may not necessarily lay down adequate consumer protection standards in the first place. But even where such standards are in place, lenders may not necessarily comply with them. The enforcement of consumer credit legislation in the Member States, therefore, deserves special attention.

Particularly in the wake of the global financial crisis, ensuring effective enforcement of the rules governing the relationship between financial institutions and their (potential) clients ranks high on the EU political agenda. Traditionally, such rules were enforced by civil courts at the initiative of one of the private parties to a dispute through the means available within national private laws. Over the past three decades or more, however, it has been increasingly recognized that private enforcement alone is insufficient for the realization of important public goals, such as the proper functioning of financial markets or a high level of financial consumer protection, and that it needs to be supplemented by public enforcement. The latter implies that the state and its agencies monitor the financial institutions' compliance with their obligations towards consumers and, in case of non-compliance, enforce them through administrative or criminal law means, such as penalties. It is the combination of public and private enforcement that is needed for achieving desired results. Many questions, however, still exist concerning the

\footnotetext{
${ }_{74}^{74}$ FCA Consumer Credit Sourcebook, section 5.5. See also FCA 2017a, p. 20.

${ }^{75}$ While the Consumer Credit Directive has been adopted as a 'full' harmonization measure, its limited scope of application and a wide margin of discretion left to Member States in such important matters as the consumer's creditworthiness assessment, have seriously undermined the ability of this directive to reduce legal fragmentation. On this in more detail, see Cherednychenko (2011).
} 
modalities of such a combination in a multi-level system of governance in the EU (Cherednychenko 2015b).

While it is beyond the scope of this article to provide a comprehensive analysis of the enforcement of European consumer law, in the following some issues that give rise to particular concern in the context of the 2008 Consumer Credit Directive will be briefly discussed with a focus on public and private enforcement.

\section{Public Enforcement}

The EU legislator has pushed Member States to establish public enforcement mechanisms in the field of European financial law, including consumer credit law. In particular, the Consumer Protection Cooperation Regulation requires Member States to set up public authorities for the enforcement of the Consumer Credit Directive. ${ }^{76}$ However, such authorities may face major challenges in ensuring the effectiveness of this directive.

In the first place, the public enforcement of responsible lending rules presents particular difficulties. The foregoing analysis of irresponsible lending practices and their drivers across the EU has shown that creative compliance in the area of consumer credit typically occurs when consumer protection standards are too vague or non-binding, which is often the case with the rules on the consumer's creditworthiness assessment. For example, in Bulgaria, Poland, and the UK, such rules have not always proved easy for the competent public authorities to enforce through administrative law means. ${ }^{77}$ While the problem often lies with the content of the legislative provisions themselves and/or the non-binding nature of the rules in question, the role of competent public authorities also deserves attention in this context. The key issue is whether such authorities are able and willing to play a pro-active role in specifying and enforcing generally formulated legislative standards of consumer protection. While the UK's FCA, for example, has embraced this role post-crisis, in many other Member States competent public authorities have been much more passive, particularly when it comes to the rules on the consumer's creditworthiness assessment. The difficulties involved in designing and enforcing such rules provide an illustration of the complexity of the "dynamics" of regulation by which the content of regulation changes over time (rule-making) and is translated from "rules on the books" into "rules in action" (supervision and enforcement) (Armour et al. 2016 , p. 80). In such circumstances, EBA has a vital role to play in providing guidance on the meaning of the open-ended provisions of the Consumer Credit Directive. However, it currently has no competence to do so under this directive.

A related but an even more fundamental issue is to what extent competent public authorities across the EU are well-equipped to effectively address consumer protection issues. The relative importance of financial consumer protection within a specific framework for financial supervision is particularly relevant in this context (cf. Reifner and Clerk-Renaud 2011; Reifner 2012). For example, a critical issue for the German Federal Financial Supervisory Authority is how to integrate financial consumer protection into its supervisory activities, given that this authority has traditionally focused on prudential supervision and that it received the consumer protection mandate only in 2015 (Ottow and Svetiev 2014). A similar

\footnotetext{
${ }^{76}$ Regulation (EU) 2017/2394 of the European Parliament and of the Council of 12 December 2017 on cooperation between national authorities responsible for the enforcement of consumer protection laws and repealing Regulation (EC) No 2006/2004 (2017) OJEU L 345/1.

${ }^{77}$ Interviews with the representatives of the Bulgarian Ministry of Economy, the Polish Office of Competition and Consumer Protection, and the UK's FCA, respectively.
} 
concern can be raised in relation to EBA and other two ESAs which are also based on the single financial regulator model (prudential supervision and conduct of business supervision (financial consumer protection) under one roof) ${ }^{78}$ Notably, according to the 2014 European Commission's report on the operation of the ESAs, the general view among stakeholders was that consumer protection had not been given sufficient priority in the work of these European agencies (European Commission 2014, p. 14). It remains to be seen whether the current reform of the European system of financial supervision, which does not envisage a clear separation between prudential supervision and conduct of business supervision, will bring about a major improvement in terms of financial consumer protection. In addition, budget constraints may also considerably limit the capacity of both European and national competent public authorities to exercise effective supervision over consumer credit markets.

Further, it is notable that the Consumer Credit Directive does not harmonize the rules on penalties applicable to infringements of the national rules implementing the provisions of this directive. The choice of sanctions therefore remains within the Member States' discretion subject to the requirement that such sanctions are effective, proportionate, and dissuasive. ${ }^{79} \mathrm{By}$ way of comparison, there are examples of EU measures that profoundly limit national procedural autonomy, in particular by harmonizing administrative sanctions. The most notable example is MiFID II which, viewed as a whole, strengthens the enforcement of the investor protection rules contained therein through administrative law means. ${ }^{80}$ This directive specifies the range of administrative sanctions, including pecuniary penalties, which should be employed for certain types of breach and how the determination as to the appropriate sanction and level of sanction should be made. ${ }^{81}$ However, as the Consumer Credit Directive does not harmonize rules on penalties to any significant degree, the solutions adopted across the EU may differ greatly. While administrative penalties are commonly used to sanction violations of consumer credit legislation, there are also Member States that have resorted to criminal sanctions for this purpose. In France, for example, exceeding the strict limits imposed by the legislation on APRC in consumer credit contracts is punishable by criminal law (up to two years in prison and a fee of EUR 300000$).{ }^{82}$ Given the large-scale mis-selling of consumer credit products in many Member States, the importance of effective public enforcement mechanisms should not be underestimated. As yet, however, no comprehensive study has been conducted into how Member States sanction violations of consumer credit legislation and to what extent the applicable sanctions actually deter lenders from unlawful behaviour.

\section{Private Enforcement}

Private enforcement of consumer credit legislation by consumers and their groups is not unproblematic either. While private enforcement through alternative dispute resolution (ADR) is increasingly gaining importance, in many Member States consumer disputes are still largely heard by civil courts. As is well-known, whether the aggrieved consumer borrower

\footnotetext{
${ }_{78}$ The role of ESAs in addressing consumer protection concerns differs from that of national competent authorities. In particular, ESA's generally do not have direct supervisory powers.

${ }^{79}$ Consumer Credit Directive, art. 23.

${ }^{80}$ It is notable, however, that MiFID II is silent on the issue of private enforcement. On the uneasy relationship between MiFID and MiFID II and national private law in more detail, see, e.g., Cherednychenko (2015a, 2015b, 2010) with further references.

${ }^{81}$ MiFID II, arts 70-72.

${ }^{82}$ Interview with the representative of the French Ministry of Economy and Finance.
} 
will be able to successfully sue a lender over its failure to observe consumer protection standards will largely depend on how accessible private litigation before a court is for the consumer in terms of time and cost involved therein and on how easy it is for the consumer to obtain relief through applicable national private law. The latter aspect deserves particular attention in the present context.

In the first place, absent the harmonization of private law remedies for violations of the Consumer Credit Directive, the traditional divide between public law (in particular financial supervision law) and private law (in particular contract and tort law) at national level may create obstacles for consumers to invoke consumer protection standards in private actions against financial institutions (Cherednychenko 2015b). In Germany, for example, the creditor's duty to assess the consumer's creditworthiness enshrined in Article 8 of the Consumer Credit Directive was initially implemented in financial supervision legislation alone, which for a long time precluded consumers from invoking private law remedies, such as damages, in case of its violation (Rott 2016). Only the 2014 ruling of the CJEU in LCL Le Crédit Lyonnais, in which the Court explicitly stated that Article 8 of the Consumer Credit Directive "is intended to protect consumers against the risks of overindebtedness and bankruptcy," ${ }^{\prime 3}$ prompted a change in the German legislator's approach and led to the introduction of detailed rules on the creditor's duty to assess the consumer's creditworthiness into the German Civil Code. ${ }^{84}$ While similar problems may exist in other Member States, at present, little is known about them.

Second, national civil procedural laws may create additional hurdles for consumers in obtaining relief in judicial proceedings. Such laws across the EU traditionally reflect the principle of party disposition under which the parties to a dispute initiate the proceedings and provide the court with facts and legal arguments. However, consumers, who are the weaker party in civil proceedings, are often unfamiliar with the legal intricacies involved in their case. In the light of the case law of the CJEU, the ex officio application of European consumer (credit) law by national courts could provide a solution. ${ }^{85}$ According to the 2017 study for the European Commission, however, at present, many national laws do not lay down such an obligation and national courts often disregard the case law of the CJEU to this effect (European Commission 2017b, p. 30 et seq.). This situation raises serious concerns about the effectiveness of the procedural protection of consumers in European consumer credit law.

The private enforcement of the Consumer Credit Directive by means of ADR has the potential to significantly improve the procedural position of consumers by providing them with low-cost, simple, and fast procedures. It is therefore not surprising that the Consumer Credit Directive requires Member States to establish adequate and effective ADR procedures for the settlement of consumer disputes concerning credit agreements. ${ }^{86}$ Notably, in the UK, the Financial Ombudsman Service (FOS) played an important role in providing redress to consumers in the aftermath of the PPI mis-selling (cf. Ferran 2012). Yet the rise of ADR in the field of financial consumer protection poses new challenges in terms of its ability to ensure compliance with consumer protection standards.

\footnotetext{
${ }_{83}$ CJEU C-565/12 LCL Le Crédit Lyonnais SA v. Fesih Kalhan, ECLI:EU:C:2014:190.

${ }^{84}$ German Civil Code $(B G B), \S 505 \mathrm{a}-\S 505 \mathrm{e}$.

85 See, e.g., CJEU C-377/14 Radlinger, ECLI:EU:C:2016:283.

${ }^{86}$ Consumer Credit Directive, art. 24.
} 
One of the major limitations of the current EU legal framework is that neither the Consumer Credit Directive nor the Directive on Consumer $\mathrm{ADR}^{87}$ requires the participation of creditors or credit intermediaries in ADR procedures to be mandatory or the outcome of such procedures to be binding on them. ${ }^{88}$ These matters, therefore, remain within the competence of Member States. Given the lack of comprehensive data, it is not entirely clear at present to what extent traders across the EU actually participate in ADR procedures in the financial services sector and accept their outcomes.

Furthermore, the rise of ADR raises concerns in terms of legal certainty. In particular, not all ADR bodies currently operating in the financial services sector are clear and consistent as to the standards they apply when resolving consumer disputes. A good illustration of the problem is provided by the case law of the dispute resolution bodies of the Dutch Financial Services Complaints Institute (Klachteninstituut Financiële Dienstverlening) - the Financial Services Complaints Commission (Geschillencommissie Financiële Dienstverlening) and the Commission of Appeal (Commissie van Beroep) in cases concerning consumer credit (Cherednychenko and Meindertsma 2014). While some cases were resolved based on the contract-related supervision rules and/or relevant industry self-regulation, ${ }^{89}$ in other cases the traditional private law duties of care and loyalty played a crucial role, either alone ${ }^{90}$ or in combination with the self-regulation. ${ }^{91}$ In addition, there are cases in which it is not clear at all what sets of norms were actually applied. ${ }^{92}$ Such divergent and contradictory approaches by ADR entities to extra-judicial private enforcement significantly undermine legal certainty for both financial institutions and consumers.

\section{Conclusions and Reflections}

In the wake of the global financial crisis, it has been widely recognized that consumer credit lending should be responsible. The major idea behind the concept of responsible lending is that lenders should not act solely in their own interests, but that they should also take into account the consumer borrowers' interests and needs throughout the relationship in order to prevent consumer detriment. Nowadays, more than a decade after the outbreak of the financial crisis, however, lenders still do not always put the consumer borrowers' interests first.

The most imminent irresponsible lending practices in the consumer credit markets across the EU that have caused consumer detriment in the past and are still a source of concern today include (1) the provision of high-cost credit, such as payday loans and credit cards, (2) crossselling, whereby consumer credit products are sold to consumers together with other products, such as payment protection insurance, and (3) peer-to-peer consumer lending (P2PL) which

\footnotetext{
${ }^{87}$ Directive 2013/11/EU of the European Parliament and of the Council of 21 May 2013 on alternative dispute resolution for consumer disputes and amending Regulation (EC) No. 2006/2004 and Directive 2009/22/EC (2013) OJEU L 165/63 (Directive on Consumer ADR).

${ }^{88} \mathrm{See}$, in particular, Directive on Consumer ADR, recital 49.

${ }^{89}$ E.g., Geschillencommissie Financiële Dienstverlening, nr. 212, 5 September 2011; Geschillencommissie Financiële Dienstverlening, nr. 2012-199, 4 July 2012; Geschillencommissie Financiële Dienstverlening, nr. 2013-17, 14 January 2013; Commissie van Beroep, nr. 2013-10, 11 March 2013; Geschillencommissie Financiële Dienstverlening, nr. 2013-219, 10 July 2013.

${ }^{90}$ E.g., Geschillencommissie Financiële Dienstverlening, nr. 189, 10 August 2011; Geschillencommissie Financiële Dienstverlening, nr. 68, 1 April 2011; Commissie van Beroep, nr. 2012-14, 21 June 2012.

91 E.g., Geschillencommissie Financiële Dienstverlening, nr. 2012-308, 31 October 2012.

92 E.g., Geschillencommissie Financiële Dienstverlening, nr. 2012-155, 16 May 2012.
} 
connects consumer lenders to consumer borrowers directly by means of an electronic P2PL platform outside the traditional financial sector. In particular, the growing digitalization of consumer finance poses new risks to consumers by facilitating quick and easy access to credit.

Irresponsible lending in the consumer credit markets is primarily driven by the market failures related to an asymmetry of information between consumers and lenders and the exploitation of consumer behavioural biases by lenders, as well as the regulatory failures to address them. While lenders are best equipped to correct the consumer borrowers' irrational preferences, in practice they often tend to take advantage of them when designing and distributing consumer credit products. Remuneration structures, such as third-party commissions, have considerable potential to misalign incentives between lenders and consumers and lead lenders to exploit consumers' ignorance or biases.

So far, regulatory interventions in the consumer credit markets have not always been able to address these problems and to ensure responsible lending. The regulatory failure in these markets across the EU results first and foremost from the lack of adequate consumer protection standards and enforcement failings at the Member State level. At the same time, close attention is needed to the role of the EU in ensuring such protection, given its harmonization efforts in this area and the large scale of irresponsible lending across the Union in the post-crisis period.

While the 2008 Consumer Credit Directive aims to achieve a high level of consumer protection against irresponsible lending, it is highly questionable whether it is well equipped to realize this objective in an increasingly digital lending environment. Reflecting the information paradigm of consumer protection and the corresponding image of the "average consumer" as a reasonably well-informed, observant, and circumspect actor, this directive fosters increased access to consumer credit and embodies only a limited concept of responsible lending. In particular, the Consumer Credit Directive does not cover small loans for less than EUR 200 and does not impose a clear borrower-focused duty on lenders to assess the consumer's creditworthiness before granting credit. Nor does it provide any substantive safeguards against potentially dangerous features of high-cost credit products, such as excessively high interest rates, unlimited rollovers, or endless possibilities to make only minimum repayments on a credit card. In addition, this directive does not address the problem of irresponsible crossselling and the new risks involved in P2PL.

Given these limitations and despite the efforts of the CJEU to address them through a consumer-friendly interpretation, the Consumer Credit Directive currently in force is likely to remain the "sleeping beauty" that would never wholly awake, like the Unfair Contract Terms Directive once did. Moreover, neither this nor other horizontal EU measures, in particular the Unfair Contract Terms Directive, can make up for major substantive limitations of the Consumer Credit Directive in combating irresponsible lending practices in the high-cost credit markets and unfair cross-selling, as well as the emerging problems in the field of P2PL. Although this directive does not preclude Member States from adopting more protective responsible lending rules, the effectiveness of the current national consumer credit regimes in ensuring responsible lending may differ considerably across the EU, given not only the content of consumer protection standards but also the way in which they are enforced. This situation may create incentives for regulatory arbitrage, whereby credit providers from Member States with strict regulations engage in cross-border activities in countries with weaker regulations.

While the European Commission aims to achieve a deeper and safer single market for consumer credit (European Commission 2017a, para. 2.6), at present, there is no coherent EU 
policy agenda in terms of addressing consumer overindebtedness. ${ }^{93}$ This may result in unjustified differences in the level of consumer protection across different segments of the consumer credit markets. Notably, the Mortgage Credit Directive adopted post-crisis has departed from the access to credit-oriented approach of the Consumer Credit Directive and introduced more protective rules designed to prevent consumer overindebtedness. In particular, this directive provides for a borrower-focused duty of lenders to assess the consumer's creditworthiness and imposes limitations on certain cross-selling practices. One may question, however, to what extent the fundamental differences in the level of consumer protection between the two directives are justified, given that problems of irresponsible lending exist not only in secured but also in unsecured credit markets, particularly those associated with high-cost credit.

In the light of this, the 2019 review of the Consumer Credit Directive should be used as an opportunity to reconsider the current approach to EU consumer credit regulation and the underlying standard of a reasonably well-informed, observant, and circumspect consumer along the lines of the concept of responsible lending. In our view, this concept should inform both the development of consumer credit products and their distribution process, while paying due regard to the principles of subsidiarity and proportionality. In particular, given the market and regulatory failures that have manifested themselves in many Member States, it should be considered whether it is appropriate to include loans below EUR 200 within the scope of the Consumer Credit Directive, to design product governance rules to be observed by lenders when developing consumer credit products, to introduce a clear borrower-focused duty of lenders to assess the consumer's creditworthiness in order to effectively address the risk of a problematic repayment situation, to introduce the lenders' duty to ensure the basic suitability of financial products offered together with credit for consumers or even restrict cross-selling practices involving product tying, and to extend the responsible lending obligations of traditional lenders to P2PL platforms. Further, it must be explored whether the EU regulatory framework for consumer credit could also be strengthened by introducing safeguards against remuneration policies that may incentivize creditors and credit intermediaries not to act in the consumers' best interests, as well as more specific and robust rules to improve public and private enforcement in this field. The role of EBA, which currently has no competence to act under the Consumer Credit Directive, deserves particular attention. This European supervisory authority could play an important role in specifying the meaning of the openended EU rules on responsible lending and ensuring a convergence of respective supervisory practices.

Regulatory experiences in the field of mortgage credit and investment services could be taken on board when operationalizing the concept of responsible lending in the area of consumer credit, with one important caveat. More intrusive consumer/retail investor protection rules which are already applicable in these sectors should not be extended to the consumer credit sector, unless this is justified by the risks for consumers in this very sector and does not impose a disproportionate regulatory burden on small non-bank lenders. After all, excessively strict consumer credit regulation may restrict access to credit and increase the borrowing costs for consumers.

In order to determine what action the EU legislator should take, further interdisciplinary research is needed to shed more light on the indicators and drivers of irresponsible consumer

${ }^{93}$ Cf. European Parliament, Resolution of 14 November 2017 on the action plan on retail financial services, P8_TA(2017)0428, para. 25. 
credit lending, as well as the best practices for addressing the problem, both in relation to standard-setting and enforcement. In particular, given the development from one consumer image to multiple consumer images in EU law, such as the responsible consumer, the confident consumer, and the vulnerable consumer (Micklitz 2016), more research is needed into the consumer image(s) in the consumer credit markets. Defining the consumer borrower image(s) is necessary in order to establish the appropriate level of consumer protection in such markets and to further operationalize the concept of responsible lending in the post-crisis lending environment. The impact of the growing digitalization of the consumer credit supply on the consumer and lender behaviour deserves special consideration in this context. The time now seems ripe for striking a different balance between access to credit and consumer protection in EU consumer credit regulation.

Open Access This article is distributed under the terms of the Creative Commons Attribution 4.0 International License (http://creativecommons.org/licenses/by/4.0/), which permits unrestricted use, distribution, and reproduction in any medium, provided you give appropriate credit to the original author(s) and the source, provide a link to the Creative Commons license, and indicate if changes were made.

\section{References}

Aldohni, A. K. (2017). The UK new regulatory framework of high-cost short-term credit: Is there a shift towards a more 'law and society' based approach? Journal of Consumer Policy, 40, 321-345.

Armour, J., Awrey, D., Davies, P., Enriques, L., Gordon, J. N., Mayer, C., \& Payne, J. (2016). Principles of financial regulation. Oxford: Oxford University Press.

Atamer, Y. M. (2011). Duty of responsible lending: Should the European Union take action? In S. Grundmann \& Y. M. Atamer (Eds.), Financial services, financial crisis and general European contract law: Failure and challenges of contracting (pp. 179-202). Alphen aan den Rijn: Kluwer Law International.

Autoriteit Financiële Markten. (2014). Markt voor flitskrediet verder opgedroogd. Statement (13 February 2014). Retrieved from https:/www.afm.nl/nl-nl/consumenten/nieuws/2014/feb/markt-flitskrediet. Accessed 10 June 2019.

Autoriteit Financiële Markten. (2017). Consultation: AFM prepares for ban on advertising of harmful financial products (21 February 2017). Retrieved from https://www.afm.nl/en/nieuws/2017/feb/consultatiereclameverbod. Accessed 10 June 2019.

Avgouleas, E. (2009a). The global financial crisis and the disclosure paradigm in European financial regulation: The case for reform. European Company and Financial Law Review, 6, 440-5.

Avgouleas, E. (2009b). The global financial crisis, behavioural finance and financial regulation: In search of a new orthodoxy. Journal of Corporate Law Studies, 9, 23-59.

Baldwin, R., Cave, M., \& Lodge, M. (2012). Understanding regulation: Theory, strategy, and practice. Oxford: Oxford University Press.

Bar-Gill, O. (2008a). The behavioural economics of consumer contracts. Minnesota Law Review, 92, 749-802.

Bar-Gill, O. (2008b). Seduction by plastic. Northwestern University Law Review, 98, 1373-1434.

Bar-Gill, O. (2009). The law, economics and psychology of subprime mortgage contracts. Cornell Law Review, 94, 1073-1152.

Better Finance. (2017). A major enforcement issue: The mis-selling of financial products (April 2017). Retrived from http://betterfinance.eu/fileadmin/user_upload/documents/Research_Reports/en/Misselling_of_ Financial_Products_in_the_EU_-_Briefing_Paper_2017.pdf. Accessed 10 June 2019.

Block-Lieb, S., \& Janger, E. (2006). The myth of the rational borrower: Rationality, behavioralism, and the misguided "reform" of bankruptcy law. Texas Law Review, 84, 1481-1565. 
Braspenning, J. J. A. (2017). Een gedragswetenschappelijk perspectief op de consumentenkredietovereeenkomst. Zutphen: Uitgeverij Parijs.

Brown, S. (2015). EU and UK consumer credit regulation: Principles, conduct, and consumer protection: Divergence or convergence of approach? European Business Law Review, 25, 555-580.

Bundesanstalt für Finanzdienstleistungsaufsicht. (2017). Ergebnisbericht zur Marktuntersuchung Restschuldversicherungen (21 June 2017). Retrived from https://www.bafin.de/SharedDocs/Downloads /DE/Anlage/dl 170620 marktuntersuchung restschuldversicherungen.html. Accessed 10 June 2019.

Cerini, D. (2016). Consumer over-indebtedness and interference with credit contracts: Italian perspective. In F. Ferretti (Ed.), Comparative perspectives of consumer over-indebtedness: A view from the UK, Germany, Greece, and Italy (pp. 345-370). The Hague: Eleven International Publishing.

Cherednychenko, O. O. (2010). The regulation of retail investment services in the EU: Towards the improvement of investor rights? Journal of Consumer Policy, 33, 403-424.

Cherednychenko, O. O. (2011). Full harmonisation of retail financial services contract law in Europe: A success or a failure? In S. Grundmann \& Y. M. Atamer (Eds.), Financial services, financial crisis and general European contract law (pp. 221-258). Alphen aan den Rijn: Kluwer Law International.

Cherednychenko, O. O. (2014). Freedom of contract in the post-crisis era: Quo vadis? European Review of Contract Law, 10, 390-421.

Cherednychenko, O. O. (2015a). Contract governance in the EU: Conceptualising the relationship between investor protection regulation and private law. European Law Journal, 21, 500-520.

Cherednychenko, O. O. (2015b). Public and private enforcement of European private law in the financial services sector. European Review of Private Law, 23, 621-647.

Cherednychenko, O.O. (2018). Irresponsible consumer credit lending across the EU in the post-crisis era, Study for the European Commission DG FISMA, June 2018 (unpublished paper on file with the author).

Cherednychenko, O. O., \& Meindertsma, J. M. (2014). Verantwoorde kredietverstrekking aan consumenten in een multilevel governancesysteem. Tijdschrift voor Consumentenrecht \& Handelspraktijken, 13, 181-191.

Cherednychenko, O.O., \& Meindertsma, J.M. (2018). Mis-selling of financial products in the European Union: Consumer credit, Study for the European Parliament's ECON Committee (June 2018). Retrieved from http:/www.europarl.europa.eu/RegData/etudes/STUD/2018/618997/IPOL_STU(2018)618997_EN.pdf. Accessed 10 June 2019.

Civic Consulting. (2017). Study on measuring consumer detriment in the European Union: Final report for Directorate-General for Justice and Consumers (February 2017). Retrieved from https://publications. europa.eu/en/publication-detail/-/publication/b0f83749-61f8-11e7-9dbe-01aa75ed71a1/language-en. Accessed 10 June 2019.

Collinson, P., \& Jones, R. (2018). Wonga collapses into administration, The Guardian (30 August 2018). Retrieved from https:/www.theguardian.com/business/2018/aug/30/wonga-collapses-into-administration. Accessed 10 June 2019.

Commission of the European Communities. (1995). Report on the operation of Directive 87/102/EEC for the approximation of the laws, regulations and administrative provisions of the Member States concerning consumer credit, COM 95(117) final. Retrieved from http://aei.pitt.edu/4843/1/4843.pdf. Accessed 10 June 2019.

Comparato, G. (2015). The design of consumer and mortgage credit law in the European system. In H.-W. Micklitz \& I. Domurath (Eds.), Consumer debt and social exclusion in Europe (pp. 9-26). Farnham: Ashgate Publishing.

Competition and Markets Authority. (2015). Payday lending market investigation: Final report (24 February 2015). Retrieved from https://assets.publishing.service.gov.uk/media/54ebb03bed915d0cf7000014/Payday_ investigation Final report.pdf. Accessed 10 June 2019.

Competition Commission. (2009). Market investigation into payment protection insurance (29 January 2009). Retrieved from http://webarchive.nationalarchives.gov.uk/20140403003432/http://www.competitioncommission.org.uk/assets/competitioncommission/docs/pdf/non-inquiry/rep_pub/reports/2009/fulltext/542. pdf. Accessed 10 June 2019.

Competition Commission. (2010). Payment protection insurance market investigation: Remittal of the point-ofsale prohibition remedy by the Competition Appeal Tribunal: Final report (14 October 2010). Retrieved from https://assets.publishing.service.gov.uk/media/5519489040f0b61401000159/report.pdf. Accessed 10 June 2019.

Domurath, I. (2013). The case for vulnerability as the normative standard in European consumer credit and mortgage law - An inquiry into the paradigms of consumer law. Journal of European and Consumer Market Law Review, 3, 124-137.

Domurath, I. (2016). Mortgage debt and the social function of contract. European Law Journal, 22, 758-771. 
Europe Economics. (2007). An analysis of the issue of consumer detriment and the most appropriate methodologies to estimate it: Final report for DG SANCO. Retrieved from http://www.europe-economics. com/publications/study_consumer_detriment.pdf. Accessed 10 June 2019.

European Banking Authority. (2015a). Opinion of the European Banking Authority on lending-based crowdfunding (26 February 2015). Retrieved from https://www.eba.europa.eu/documents/10180/983359 /EBA-Op-2015-03+\%28EBA+Opinion+on+lending+based+Crowdfunding\%29.pdf. Accessed 10 June 2019.

European Banking Authority. (2015b). Guidelines on creditworthiness assessment: Final report (1 June 2015). Retrieved from https://www.eba.europa.eu/documents/10180/1092161/EBA-GL-2015-11 +Guidelines+on+creditworthiness+assessment.pdf. Accessed 10 June 2019.

European Banking Authority. (2016). Guidelines on product oversight and governance arrangements for retail banking products (22 March 2016). Retrieved from https:/www.eba.europa.eu/documents/10180/1141044 /EBA-GL-2015-18+Guidelines+on+product+oversight+and+governance.pdf. Accessed 10 June 2019.

European Banking Authority. (2017). EBA consumer trends report 2017, (28 June 2017). Retrieved from https:/www.eba.europa.eu/documents/10180/1720738/Consumer+Trends+Report+2017.pdf. Accessed 10 June 2019.

European Central Bank. (2017). Guidance to banks on non-performing loans (March 2017). Retrieved from https://www.bankingsupervision.europa.eu/ecb/pub/pdf/guidance_on_npl.en.pdf. Accessed 10 June 2019.

European Central Bank. (2019a). Statistical data warehouse: Bank interest rates statistics. Retrieved from http://sdw.ecb.europa.eu/reports.do?node=1000005691. Accessed 10 June 2019.

European Central Bank. (2019b). Statistical data warehouse: Payments and settlement systems statistics. Retrieved from https://sdw.ecb.europa.eu/browse.do?node=9689709. Accessed 10 June 2019.

European Coalition for Responsible Credit. Principles of responsible credit. Retrieved from http://www. responsible-credit.net/index.php?id=2516. Accessed 10 June 2019.

European Commission. (2008). Towards a common operational European definition of over-indebtedness. Retrieved from http://www.oee.fr/files/study_overindebtedness_en.pdf. Accessed 10 June 2019.

European Commission. (2014). Report from the Commission to the European Parliament and the Council on the operation of the European Supervisory Authorities (ESAs) and the European System of Financial Supervision (ESFS) SWD(2014) 261 final. Retrieved from http://eur-lex.europa.eu/legalcontent/EN/TXT/HTML/?uri=CELEX:52014DC0509\&from=EN. Accessed 10 June 2019.

European Commission. (2015). Green paper on retail financial services: Better products, more choice, and greater opportunities for consumers and businesses COM(2015) 630 final. Retrieved from http://eur-lex. europa.eu/legal-content/EN/TXT/?uri=COM:2015:630:FIN. Accessed 10 June 2019.

European Commission. (2016a). Consumer markets scoreboard: Making markets work for consumers. Retrieved from https:/ec.europa.eu/info/sites/info/files/consumer_markets_scoreboard_2016_en.pdf. Accessed 10 June 2019.

European Commission. (2016b). Guidance on the implementation / application of directive 2005/29/EC on unfair commercial practices, SWD(2016) 163 final. Retrieved from https://eur-lex.europa.eu/legalcontent/EN/TXT/?uri=CELEX\%3A52016SC0163. (Accessed 10 June 2019).

European Commission. (2017a). Action plan: Better products, more choice, Communication from the Commission to the European Parliament, the Council, the European Central Bank, the European Economic and Social Committee and the Committee of the Regions, COM(2017) 139 final. Retrieved from https://eur-lex.europa.eu/resource.html?uri=cellar:055353bd-0fba-11e7-8a35-01 aa75ed71a1.0003.02 /DOC_1\&format=PDF. Accessed 10 June 2019.

European Commission. (2017b). An evaluation study of national procedural laws and practices in terms of their impact on the free circulation of judgments and on the equivalence and effectiveness of the procedural protection of consumers under EU consumer law, Report prepared by a consortium of European universities led by the MPI Luxembourg for procedural law as commissioned by the European Commission, June 2017. Retrieved from https:/publications.europa.eu/en/publication-detail/-/publication/531ef49a-9768-11e7-b92d01aa75ed71a1/language-en. Accessed 10 June 2019.

European Commission. (2017c). Legislative proposal for an EU framework on crowd and peer to peer finance: Inception impact assessment (30 October 2017). Retrieved from https://ec.europa.eu/info/law/betterregulation/initiatives/ares-2017-5288649_en. Accessed 10 June 2019.

European Commission. (2018). Proposal for a regulation of the European Parliament and of the Council on European crowdfunding service providers (ECSP) for business COM(2018) 113. Retrieved from https://eurlex.europa.eu/legal-content/EN/TXT/?uri=CELEX\%3A52018PC0113. Accessed 10 June 2019 .

European Financial Inclusion Network Research Working Group on Over-Indebtedness. (2016). Unfair lending practices and toxic loans December (2016). Retrieved from https://www.finance-watch.org/wpcontent/uploads/2018/12/EFIN-Unfair-Lending-Practices-and-Toxic-Loans-VF-6Dec.pdf. Accessed 10 June 2019. 
European Parliament. (2014). Consumer protection aspects of financial services: Study, February 2014. Retrieved from http://www.europarl.europa.eu/RegData/etudes/etudes/join/2014/507463/IPOL-IMCO_ ET(2014)507463 EN.pdf. (Accessed 10 June 2019).

Fejõs, A. (2015). Achieving safety and affordability in the UK payday loans market. Journal of Consumer Policy, $38,181-202$.

Ferran, E. (2012). Regulatory lessons from the payment protection insurance mis-selling scandal in the UK. European Business Organization Law Review, 13, 247-270.

Ferretti, F. (2007). The regulation of consumer credit information systems: Is the EU missing a chance? Legal Issues of Economic Integration, 34, 115-131.

Ferretti, F., \& Livada, C. (2016). The over-indebtedness of European consumers under EU policy and law. In F. Ferretti (Ed.), Comparative perspectives of consumer over-indebtedness: A view from the UK, Germany, Greece, and Italy (pp. 11-37). The Hague: Eleven International Publishing.

Financial Conduct Authority. (2014). Detailed rules for the FCA regime for consumer credit, including feedback on FCA QCP 13/18 and 'made rules', February 2014, PS 14/3. Retrieved from https://www.fca.org. uk/publication/policy/ps14-03.pdf. Accessed 10 June 2019.

Financial Conduct Authority. (2015). Creditworthiness and affordability: Common misunderstandings, (June 2015, updated October 2016). Retrieved from https:/www.fca.org.uk/publication/consumer-creditinformation/consumer\%20credit-understanding-cc-creditworthiness-affordability-web.pdf. Accessed 10 June 2019.

Financial Conduct Authority. (2016). Credit card market study: Final findings report (July 2016). Retrieved from https://www.fca.org.uk/publication/market-studies/ms14-6-3-credit-card-market-study-final-findings-report. pdf. Accessed 10 June 2019.

Financial Conduct Authority. (2017a). Assessing creditworthiness in consumer credit: Proposed changes to our rules and guidance, CP17/27, (July 2017). Retrieved from https://www.fca.org. uk/publication/consultation/cp17-27.pdf. Accessed 10 June 2019.

Financial Conduct Authority. (2017b). Credit card market study: Persistent debt and earlier intervention remedies - Feedback on CP17/10 and further consultation, (December 2017). Retrieved from https:/www.fca.org.uk/publication/consultation/cp17-43.pdf. Accessed 10 June 2019.

Financial Conduct Authority. (2018a). Credit card market study: Persistent debt and earlier intervention feedback to CP17/43 and final rules, PS18/4, (February 2018). Retrieved from https://www.fca.org. uk/publications/policy-statements/ps18-04-credit-card-market-study. Accessed 10 June 2019.

Financial Conduct Authority. (2018b). Staff incentives, remuneration and performance management in consumer credit - Feedback to CP17/20 and final rules, PS18/7, (March 2018). Retrieved from https://www.fca.org. uk/publication/policy/ps18-07.pdf. Accessed 10 June 2019.

Financial Conduct Authority. (2019). Monthly PPI refunds and compensation. Retrieved from https://www.fca. org.uk/news/ppi-monthly-refunds-compensation. Accessed 10 June 2019.

Financial Services Authority. (2006). The sale of payment protection insurance: Results of follow-up thematic work (October 2006).

Financial Services Authority. (2007). The sale of payment protection insurance: Thematic update (October 2007).

Financial Services Authority. (2008). Payment protection insurance: A thematic update (October 2008).

Garcia Porras, C. I., \& Van Boom, W. H. (2012). Information disclosure in the EU Consumer Credit Directive: Opportunities and limitations. In J. Devenney \& M. Kenny (Eds.), Consumer credit, debt and investment in Europe (pp. 21-55). Cambridge: Cambridge University Press.

Grundmann, S. (2016). Targeted consumer protection. In D. Leczykiewicz \& S. Weatherill (Eds.), The images of the consumer in EU law: Legislation, free movement and competition law (pp. 223-244). Oxford: Hart Publishing.

Grundmann, S., Möslein, F., \& Riesenhuber, K. (2015). Contract governance: Dimensions in law and interdisciplinary research. In S. Grundmann, F. Möslein, \& K. Riesenhuber (Eds.), Contract governance: Dimensions in law and interdisciplinary research (pp. 3-57). Oxford: Oxford University Press.

Harris C., \& Laibson, D. (2013). Instantaneous Gratification. Quarterly Journal of Economics, 128, $205-248$.

International Financial Consumer Protection Organisation (FinCoNet). (2017). Report on the digitalisation of short-term, high-cost consumer credit (November 2017). Retrieved from http://www.finconet. org/Digtalisation-Short-term-High-cost-Consumer-Credit.pdf. Accessed 10 June 2019.

Joint Committee of the European Supervisory Authorities. (2014). Joint Committee consultation paper on guidelines for cross-selling practices, (22 December 2014). Retrieved from https://www.eba.europa. eu/documents/10180/936747/JC+CP+2014+05+(Consultation+Paper+on+Cross+Selling).pdf. Accessed 10 June 2019.

Jørgensen, T. (2015). Harmonisation: A need for EU action on consumer credit? European Business Law Review, 26, 743-764. 
Livada, C. (2016). The Greek regulatory framework on responsible lending. In F. Ferretti (Ed.), Comparative perspectives of consumer over-indebtedness: A view from the UK, Germany, Greece, and Italy (pp. 247258). The Hague: Eleven International Publishing.

Macchiavello, E. (2017). Financial-return crowdfunding and regulatory approaches in the shadow banking, fintech and collaborative finance era. European Company and Financial Law Review, 14, 662-722.

Mak, V., \& Braspenning, J. (2012). Errare humanum est: Financial literacy in European consumer credit law. Journal of Consumer Policy, 35, 307-322.

Mann, R. J. (2007). Bankruptcy reform and the "sweatbox" of credit card debt. University of Illinois Law Review, 2007, 375-404.

Micklitz, H.-W. (2010). The paradox of access to financial services for consumers. European Journal of Consumer Law, 7-26.

Micklitz, H.-W. (2015). Herd behaviour and third party impact as a legal concept: On tulips, pyramid games, and asset-backed securities. In S. Grundmann, F. Möslein, \& K. Riesenhuber (Eds.), Contract governance: Dimensions in law and interdisciplinary research (pp. 106-146). Oxford: Oxford University Press.

Micklitz, H.-W. (2016). The consumer: Marketised, fragmentised, constitutionalised. In D. Leczykiewicz \& S. Weatherill (Eds.), The images of the consumer in EU law: Legislation, free movement and competition law (pp. 21-41). Oxford: Hart Publishing.

Micklitz, H.-W., \& Reich, N. (2014). The court and sleeping beauty: The revival of the unfair contract terms directive (UCTD). Common Market Law Review, 51, 771-808.

Moloney, N. (2012). The investor model underlying the EU's investor protection regime: Consumers or investors? European Business Organization Law Review, 13, 169-193.

Nield, S. (2012). Mortgage finance: Who's responsible? In J. Devenney \& M. Kenny (Eds.), Consumer credit, debt and investment in Europe (pp. 160-181). Cambridge: Cambridge University Press.

Office of Fair Trading. (2011). Irresponsible lending - OFT guidance for creditors, OFT 1107, (March 2010), updated February 2011. Retrieved from http://webarchive.nationalarchives.gov.uk/20140402162813 /http://www.oft.gov.uk/OFTwork/publications/publication-categories/guidance/consumer_credit_ act/oft1107. Accessed 10 June 2019.

Office of Fair Trading. (2013). Payday lending: Compliance review final report (March 2013). Retrieved from https://assets.publishing.service.gov.uk/media/532ad55eed915d0e5d00038d/oft1481.pdf. Accessed 10 June 2019.

Osborne, H. (2008). Liverpool Victoria fined over $£ 840.000$ over PPI failings, The Guardian, (30 July 2008). Retrieved from https://www.theguardian.com/money/2008/jul/30/ppi.insurance. Accessed 10 June 2019.

Ottow, A., \& Svetiev, Y. (2014). Financial supervision in the interstices between private and public law. European Review of Contract Law, 10, 496-544.

Ramsay, I. (2005). From truth in lending to responsible lending. In G. Howells, A. Jansen, \& R. Schulze (Eds.), Information rights and obligations (pp. 47-65). Aldershot: Ashgate.

Ramsay, I. (2012). Consumer credit regulation after the fall: International dimensions. Journal of European Consumer and Market Law, 1, 24-34.

Ramsay, I. (2016). Changing policy paradigms of EU consumer credit and debt regulation. In D. Leczykiewicz \& S. Weatherill (Eds.), The images of the consumer in EU law: Legislation, free movement and competition law (pp. 159-182). Oxford: Hart Publishing.

Reifner, U. (2012). Financial services and consumer protection - From private law to bank supervision. In E. Buttigieg (Ed.), Rights and remedies for the consumer in the European Union (pp. 99-124). Malta: Gutenberg Press.

Reifner, U. (2017). Systemischer Kreditwucher am Beispiel der Targobank (Citibank), Iff-infobriefe 7-13/2017 (on file with the author).

Reifner, U., \& Clerk-Renaud, S. (2011). Financial supervision in the EU: A consumer perspective (February 2011). Retrieved from http://www.responsible-credit.net/media.php?t=media\&f=file\&id=4237. Accessed 10 June 2019.

Reifner, U., Clerk-Renaud, S., \& Knobloch, R.A.M. (2010). Study on interest rate restrictions in the EU: Final report. Retrieved from https://publications.europa.eu/en/publication-detail/-/publication/46a336d0-18a04b46-8262-74f0e0f47eb3. Accessed 10 June 2019.

Rott, P. (2016). Insufficient prevention of over-indebtedness - Legal and policy failures. In F. Ferretti (Ed.), Comparative perspectives of consumer over-indebtedness: A view from the UK (pp. 189-205). Germany, Greece, and Italy: The Hague: Eleven International Publishing.

Sunstein, C. R. (2006). Boundedly Rational Borrowing. University of Chicago Law Review, 73, 249-270.

Williamson, T. (2013). Continuity, not rupture: The persistence of neoliberalism in the internationalization of consumer finance regulation. In T. Wilson (Ed.), International responses to issues of credit and overindebtedness in the wake of crisis (pp. 15-46). Farnham: Ashgate.

Wonga. (2018). Retrieved from https://www.wonga.com/fast-cash-advances. Accessed 13 April 2018. 
Zhang, B., Wardrop, R., Ziegler, T., Lui, A., Burton, J., James, A., \& Garvey, K. (2016a). Sustaining momentum - the 2nd annual European alternative finance industry survey (September 2016). Retrieved from https://www.jbs.cam.ac.uk/fileadmin/user_upload/research/centres/alternative-finance/downloads/2016european-alternative-finance-report-sustaining-momentum.pdf. Accessed 13 April 2018.

Zhang, B., Baeck, P., Ziegler, T., Bone, J., \& Garvey, K. (2016b). Pushing boundaries: The 2015 UK alternative finance industry report (February 2016). Retrieved from https://www.jbs.cam.ac.uk/fileadmin/user upload/research/centres/alternative-finance/downloads/2015-uk-alternative-finance-industry-report.pdf. Accessed 13 April 2018.

Publisher's Note Springer Nature remains neutral with regard to jurisdictional claims in published maps and institutional affiliations. 